Economia e Sociedade, Campinas, Unicamp. IE. http://dx.doi.org/10.1590/1982-3533.2021v30n3art01

\title{
Subdesenvolvimento brasileiro à luz de Celso Furtado: uma "radiografia" da estrutura distributiva de renda no país *
}

\author{
Alanna Santos de Oliveira ** \\ Carlos Alves do Nascimento ***
}

\begin{abstract}
Resumo
O subdesenvolvimento brasileiro, na forma como foi qualificado por Celso Furtado, evidencia natureza notadamente distributiva derivada da conexão precisa entre dependência cultural externa e exploração interna do trabalhador. Apesar do diagnóstico que data de algumas décadas, nuances da estrutura distributiva no período recente permitem o reconhecimento da relevância e atualidade dessa interpretação, de modo que a análise de informações mapeadas em uma ampla "radiografia" da distribuição de renda brasileira constituiu o objetivo deste trabalho. Procurou-se responder se o que se passou, desde o último escrito de Celso Furtado, teria modificado as condições mais fundamentais por ele descritas. De uma forma geral, as informações aqui tratadas, à luz de Furtado, sugeriram a persistência do subdesenvolvimento brasileiro, avaliado a partir das estruturais assimetrias socioeconômicas que ainda o compõem.
\end{abstract}

Palavras-chave: Subdesenvolvimento, Brasil, Celso Furtado, 1920-2004, Distribuição de renda.

\begin{abstract}
Brazilian underdevelopment according to Celso Furtado: a "radiograph" of the income distribution structure in the country Brazilian underdevelopment, as qualified by Celso Furtado, shows a notably distributive nature derived from the close relationship between external cultural dependence and the internal exploitation of workers. Despite the fact that this diagnosis dates back decades, nuances of the distributive structure in recent times highlight the current relevance of this interpretation, in such a way that the analysis of information mapped in a comprehensive "radiograph" of Brazilian income distribution was the objective of this work. It aimed at answering if what has happened, since Celso Furtado's last study, would have changed the most fundamental conditions described by him. In general, the information analyzed here, according to Furtado, suggested the persistence of Brazilian underdevelopment, as assessed based on the structural socioeconomic asymmetries of which it is still composed.
\end{abstract}

Keywords: Underdevelopment, Brazil, Celso Furtado, 1920-2004, Income distribution. JEL: O15.

\section{Introdução}

Partindo da concepção furtadiana de que o estudo do subdesenvolvimento, em vista de suas especificidades, requer instrumental adequado à análise dessa realidade - uma vez que este fenômeno, sem uma devida intervenção, reproduz-se continuadamente como desdobramento do seu contato permanente com o centro do sistema capitalista que se renova indefinidamente -, este trabalho adota, portanto, o método estruturalista para tratamento do tema. No Brasil, Celso Furtado figura entre os maiores expoentes do pensamento estruturalista, detentor de vasta obra literária que, em grande parte,

\footnotetext{
${ }^{*}$ Artigo recebido em 28 de janeiro de 2020 e aprovado em 5 de julho de 2021.

${ }^{* *}$ Pesquisadora do Centro de Estudos, Pesquisas e Projetos Econômico-Sociais (CEPES) da Universidade Federal de Uberlândia, Uberlândia, MG, Brasil. E-mail: alanna.santos@ufu.br. ORCID: https://orcid.org/0000-0002-9090-8367.

*** Professor na Graduação e na Pós-Graduação do Instituto de Economia e Relações Internacionais da Universidade Federal de Uberlândia, Uberlândia, MG, Brasil. E-mail: carlos.nascimento@ufu.br. ORCID: https://orcid.org/0000-0003-3495-8076.
} 
é voltada à exposição de sua teoria do subdesenvolvimento latino-americano, com enfoque particular na economia brasileira.

$\mathrm{O}$ autor dedicou a maior parte de sua vida à tentativa de compreender as mazelas que constituem o universo subdesenvolvido, agregando a esse esforço a reflexão acerca de proposições práticas para superação dessa condição. Após uma jornada de aproximadamente seis décadas dedicadas incansavelmente à interpretação econômica, social, cultural e política do Brasil, ainda na virada do milênio, o autor diagnosticava "O Longo Amanhecer" que o país tinha pela frente, tecendo referências ao mimetismo cultural e consumismo, fundamentos do grande poder do capital na era da transnacionalização e da crescente participação deste na apropriação da renda, tudo isso contribuindo para a degeneração de uma estrutura social que nunca conheceu grandes avanços, no caso particular do Brasil.

A esse respeito, Furtado ainda se perguntava “Que Fazer?” e iniciava sua resposta indicando - algo que sempre esteve presente em sua longa vida curtida na reflexão intelectual atuante - que "O objetivo a alcançar a longo prazo deve ser uma reforma de estruturas visando a retomar o processo de construção a cuja interrupção me referi em livro publicado no começo do decênio"1 (Furtado, 1999, p. 32; itálico nosso). E entre as três frentes apontadas pelo autor, de uma estratégia de superação do subdesenvolvimento a ser seguida, a primeira - que interessa mais de perto neste artigo - "visa a reverter o processo de concentração patrimonial e de renda que está na raiz das malformações sociais que se observam no Brasil" (Furtado, 1999, p. 32; itálico nosso).

Diante das inovações cada vez mais céleres do capitalismo, resta indagar se o que se passou, desde seu falecimento em 2004, teria modificado as condições mais fundamentais por ele descritas. Teria o Brasil finalmente superado o subdesenvolvimento tal como apreendido por Furtado? Seria ainda relevante o vasto arcabouço teórico do autor para interpretação da realidade brasileira nos tempos atuais? Essas questões iluminaram o estudo sobre o qual se buscou refletir neste trabalho.

Tendo como base a compreensão deste autor com respeito ao subdesenvolvimento brasileiro, a qual sugere um modelo estabelecido da conexão precisa entre dependência externa e exploração interna, visa-se à apresentação de um conjunto extensivo de dados que reflitam a presença, reprodução e persistência de elevada heterogeneidade socioeconômica no país, e que historicamente desvela a essência do subdesenvolvimento brasileiro. É justamente essa antinomia, a dificuldade de socialização dos frutos do progresso (e o caráter instrumental deste) que retrata com precisão a continuidade do subdesenvolvimento no Brasil.

As razões por detrás disso se figuram as mesmas já amplamente apontadas por Furtado, vez que se mantêm inalteradas as estruturas de poder no país. A aviltante correlação de forças entre proprietários e assalariados, mesmo tendo conhecido ligeira melhoria no decorrer da primeira década dos anos 2000, permitindo leve afrouxamento no modelo neoliberal, não deu lugar a uma transformação do ponto de vista estrutural, por conseguinte, de ruptura com os alicerces da exploração sedimentada.

Refletir acerca do subdesenvolvimento brasileiro requer, portanto, lançar um olhar detido para a dificuldade de homogeneização social historicamente colocada no país. Para tanto, o que se

(1) Furtado se refere ao seu livro "Brasil: a construção interrompida" (1992). 
propõe aqui é uma análise aprofundada de dados que caracterizam a estrutura distributiva da renda no Brasil, evidenciando, desse modo, a natureza fundamental do subdesenvolvimento na perspectiva furtadiana, qual seja, a elevada assimetria socioeconômica. Diagnóstico e preocupação que Furtado reiteradamente expõe em seus textos, tal como ainda indagava, no entardecer de sua vida, quando com renovada esperança ${ }^{2}$ encontrava-se "Em busca de um novo modelo": "por que o Brasil se singulariza pela concentração da renda e da riqueza? Como explicar que seja o nosso país praticamente o campeão mundial de desigualdades sociais?" (Furtado, 2002, p. 12) ${ }^{3}$.

A obra de Furtado, na esteira dessas indagações, a qualquer tempo, mas, sobretudo a partir do esgotamento do processo modernizante de substituição de importações, deixa claro que a dependência externa cultural, a qual conforma peça chave na sua análise do excedente, tem por sustentação central a exploração interna da classe trabalhadora, por meio da histórica compressão de salários viabilizada pela persistência de um setor de subsistência, com características notadamente mais amplas do que a priori o termo poderia evocar. Ao mesmo tempo em que se traduz em instrumento, configura ela mesma - a exploração interna - em produto indissociável do subdesenvolvimento, ao constituir uma de suas malformações elementares.

A análise da estrutura distributiva brasileira à luz da interpretação de Celso Furtado quanto ao subdesenvolvimento requer atenção a dados que extrapolam a simples mensuração da desigualdade pelos indicadores mais tradicionais. Por essa razão, e em conformidade com Furtado (1977), propõese uma investigação em múltiplas dimensões assentada em uma morfologia do excedente e das estruturas de poder no país.

A análise dessa morfologia necessita inicialmente, após esta introdução, da exposição da teoria do subdesenvolvimento brasileiro elaborada por Furtado, destacando-se a relevância do conceito de heterogeneidade social como substrato teórico fundamental desse fenômeno. Dimensionada a perceptiva distributiva, sobretudo de viés funcional na análise do autor, prosseguese, na seção seguinte, com uma breve síntese dos principais elementos conformadores do mercado de trabalho no Brasil, chamando atenção para características muito particulares desse processo que desembocam numa configuração específica de distribuição de riqueza e renda no país. Um fatorchave nessa dimensão diz respeito à existência e persistência ao longo do tempo de um setor de subsistência com importância estratégica para a concentração no país.

Feito isso, passa-se, então, à apresentação dos dados mais recentes que compõem a radiografia da estrutura distributiva brasileira. Os indicadores mais tradicionais de mensuração da desigualdade e concentração da renda são analisados, como os Índices de Theil e Coeficiente de Gini

(2) Ser movido por Esperança - na superação do subdesenvolvimento brasileiro - parece ser uma marca indelével desse magistral pensador. Algo que ele mesmo explicita - após sintetizar suas ideais desenvolvidas ao longo de longos quarenta anos de reflexão, em cujo centro dessa síntese encontra-se o tema da profunda desigualdade socioeconômica -, dirigindo-se aos jovens economistas (na ocasião do recebimento do título de Doutor "Honoris Causa" da Unicamp): "Não posso terminá-lo sem expressar minha esperança de que a atual geração de economistas ilumine com ideias novas os difíceis caminhos na busca da superação do subdesenvolvimento" (Furtado, 1992, p. 17; itálico nosso)

(3) Após discutir alguns aspectos relativos a essas indagações - tais como, a inadequada estrutura agrária, a persistência do problema da fome, do déficit habitacional, da pobreza, do sistema tributário injusto, da relação entre aculturação e padrões de consumo -, Furtado assim resume seu pensamento: "Cabe a pergunta: houve desenvolvimento? Não: o Brasil não se desenvolveu; modernizou-se. O desenvolvimento verdadeiro só existe quando a população em seu conjunto é beneficiada" (Furtado, 2002, p. 20). 
calculados a partir da PNAD (Pesquisa Nacional por Amostra de Domicílios). Adicionalmente, são exploradas as informações provenientes da DIRPF (Declaração do Imposto de Renda Pessoa Física), as quais permitem resultados um pouco distintos dos da referida pesquisa. A estrutura fundiária também é enfocada, por meio dos dados do Censo Agropecuário e do DATALUTA. De igual modo, analisam-se informações que oferecem uma caracterização mais geral do sistema tributário brasileiro (no que diz respeito à taxação pessoal da renda); do mercado consumidor, por meio da POF (Pesquisa de Orçamento Familiar); e, por fim, do mercado de trabalho, a partir da PNAD e também de dados da RAIS (Relação Anual de Informações Sociais).

Espera-se que a análise de todas essas informações seja suficiente para prover os indícios necessários ao reconhecimento da reprodução do subdesenvolvimento no país, nos termos apreendidos por Furtado, ressaltando a atualidade de seu diagnóstico que, em última instância, evidencia a opção histórica por um determinado modelo de crescimento e desenvolvimento. Por fim, com essas reflexões em mente, são tecidas as considerações finais do trabalho.

\section{$1 O$ subdesenvolvimento na concepção de Celso Furtado}

Uma das preocupações centrais impressas na obra intelectual de Furtado reflete-se na elaboração de uma teoria típica do subdesenvolvimento, capaz de apreender a realidade da periferia latino-americana. Seu esforço, ao transmitir uma interpretação social e econômica do Brasil, consolida uma reflexão autêntica acerca das bases de conformação do país, ressaltando, sobretudo, o cerne cultural de suas malformações e a relação viciosa que constitui a essência do subdesenvolvimento, qual seja, entre dependência externa e exploração interna.

Seu método de análise repousa na perspectiva histórico-estruturalista, retratando o condicionamento da periferia às transformações que se processam continuamente no centro do sistema capitalista, respondendo por longo período como mero prolongamento das economias mais dinâmicas. O marco referencial do autor certamente encontra-se na $1^{\mathrm{a}}$ Revolução Industrial (Furtado, 1961), cujo desdobramento resultou na conformação de uma divisão internacional entre países desenvolvidos e subdesenvolvidos. O cerne dessa distinção se coloca no modo como cada país logra participar dos processos de transformações engendradas por aquela revolução (e também pelas seguintes $),{ }^{4}$ e cuja natureza elementar encontra-se nos expressivos ganhos de produtividade em cada país.

A partir da análise quanto à forma de obtenção dos ganhos de produtividade, Furtado desenvolve seu diagnóstico do subdesenvolvimento por meio da elaboração de sua "teoria do

(4) Furtado (1961) observa que o subdesenvolvimento é resultado do contato permanente entre os países periféricos e o que ele denomina por "núcleo industrial originário" (fazendo referência aos países centrais que lograram alcançar o estágio de constituição de um sistema industrial nacional assentado na capacidade sempre renovada de criação de ciência e tecnologia). Para o autor, o aspecto mais fundamental que distingue o desenvolvimento do subdesenvolvimento é a capacidade que o primeiro tem - e da qual o segundo carece de articular acumulação de capital com desenvolvimento científico-tecnológico. Nesse sentido é que o termo originário atribuído ao grupo dos países centrais não significa algo do passado associado exclusivamente à $1^{\text {a }}$ Revolução Industrial, mas que se refere à capacidade que aquele núcleo central de países tem de continuamente renovar-se científica e tecnologicamente, de permanentemente originar-se (Wasques, 2018). Ao irradiar-se, portanto, continuamente em direção às periferias, aquele núcleo central condiciona a reprodução do subdesenvolvimento dessas sociedades/economias. O nexo que Furtado encontra entre desenvolvimento e subdesenvolvimento, por conseguinte, consiste primordialmente na dependência cultural do segundo em relação ao primeiro, fruto daquele contato recorrentemente renovado, que, por sua vez, reproduz forçosamente a conexão entre dependência externa e exploração/dominação interna (Hadler, 2012). 
excedente social". Segundo ele, é a partir de uma destinação específica dada ao excedente que se configura a mais perniciosa forma de dependência - a cultural -, a qual norteia todo o processo de acumulação dessas economias e que resulta nitidamente incoerente com o desenvolvimento das forças produtivas internas.

A utilização do excedente na periferia do sistema capitalista não apresenta vinculação suficiente ao processo de formação de capital nos setores produtivos, e essa é uma das principais raízes por detrás do fenômeno do subdesenvolvimento. A apropriação da renda nessas economias é feita por um grupo minoritário, a elite dirigente, que o emprega para obtenção de objetos de consumo típicos das sociedades desenvolvidas. É justamente essa demanda elitizada, cujos produtos requeridos são de natureza tecnológica profundamente desconectada da estrutura social e produtiva alcançadas, que dirige as transformações mais expressivas por que passam essas economias.

Aqui se funda, portanto, o conceito de modernização em Celso Furtado, ou seja, na periferia do sistema ocorre a cópia dos padrões de consumo e estilos de vida dos países avançados sem, por um lado, um correspondente acúmulo de capital (e progresso técnico) nos setores produtivos e, por outro, eliminação da oferta elástica de mão-de-obra. Conforme denota o autor em "Análise do 'Modelo' Brasileiro", o descompasso entre a acumulação no eixo do consumo e no que concerne ao desenvolvimento das forças produtivas tem por raiz o comportamento mimético da elite brasileira e instrumentaliza-se na inadequação da tecnologia adotada, tendo em vista a dificuldade de formação de capital no país, e apoia-se fortemente em um processo estrutural de concentração da renda.

A fraca articulação entre as modificações que se processam na estrutura produtiva brasileira (estimuladas pela acumulação no eixo do consumo) e a estrutura social, que permanece praticamente inalterada na ausência de um correspondente processo de homogeneização social, denota a inadequação da tecnologia incorporada face às necessidades de desenvolvimento das forças produtivas no país. ${ }^{5}$ Esse configura, portanto, um aspecto fundamental de diferenciação da industrialização ocorrida no Brasil daquela que se processou no centro do sistema capitalista marcada pela presença de anéis de feedback, os quais denotam que as transformações que têm lugar no eixo produtivo encontram correspondência nas evoluções da estrutura social que, por sua vez, retroalimentam o virtuoso sistema de acumulação e delineiam a dialética fundamental do desenvolvimento.

O perfil de demanda que dirige o processo de formação de um sistema econômico nesses países, e que origina a industrialização nestes, requer um grau de técnica que dispensa fortemente o fator trabalho, fato que, em sociedades com elevada oferta relativa de mão-de-obra, contribui para determinação dos salários a níveis extremamente baixos, denotando a alta taxa de exploração interna a que esse sistema de modernização faz jus.

Sob essa perspectiva, a distribuição da renda é um reflexo nessas economias da pressão gerada pela modernização, o que quer dizer que a mimetização dos hábitos de consumo empreendida por uma minoria responde pela orientação das técnicas produtivas a ser adotada. A tecnologia em questão corrobora para uma oferta elástica de mão de obra, bem como para o diferencial de salários

(5) "A inadequação da tecnologia, a que se referiram alguns economistas, de um ângulo de vista sociológico traduziu-se na polaridade modernização-marginalidade" (Furtado, 1980, p. 25; itálico no original). 
entre o setor que está se industrializando e o setor de subsistência. Neste contexto, o crescimento econômico se faz compatível com o aprofundamento das desigualdades econômico-sociais, requerendo, para tanto, tão somente o contorno das tensões político-sociais derivadas desse processo de aviltante diferenciação no plano interno.

Ademais, se se tem em conta que a situação de dependência está sendo permanentemente reforçada, mediante a introdução de novos produtos [...] torna-se evidente que o avanço do processo de industrialização depende de aumento da taxa de exploração, isto é, de uma crescente concentração da renda. Em tais condições, o crescimento econômico tende a depender mais e mais da habilidade das classes que se apropriam do excedente para forçar a maioria da população a aceitar crescentes desigualdades sociais (Furtado, 1974, p. 88-89).

Dois aspectos fundamentais de sua teoria, que permanecem até suas últimas análises, referemse, portanto, à natureza notadamente cultural do problema do subdesenvolvimento, manifestada na tentativa de reproduzir/imitar um padrão de consumo característico de sociedades que dispõem de um processo de acumulação em estágio já mais avançado - o que, historicamente, respondeu por desequilíbrios no Balanço de Pagamentos; e ao reflexo inequívoco desse fenômeno na estrutura distributiva, configurando autêntica situação de exploração interna.

Concentrando-se nas peculiaridades da estrutura socioeconômica dessas sociedades, Furtado (1965, 1966) ressalta a relevância de elementos institucionais por detrás do desenvolvimento econômico. O latifúndio revelou-se uma das instituições básicas da estrutura política e social das economias latino-americanas. Juntamente com esse elemento, de significado e importância elementares seria a convivência entre dois setores nessas sociedades: um de cunho capitalista e outro pré-capitalista. A existência desse último permitiu durante longo período que as taxas de salários se colocassem como função do nível de vida (extremamente baixo) nesse setor mais arcaico, ao invés de se relacionar com a produtividade do trabalho. Assim, colocava-se o eixo fundamental da oferta elástica de mão-de-obra por meio da qual essas economias se "desenvolveram" materialmente falando.

Desse modo, deve-se ressaltar que são os fatores histórico-institucionais que, a priori, garantem uma concentração estrutural da renda a favor dos lucros no país (e de uma classe notadamente minoritária), delineada, em especial, pela persistência de um setor de subsistência ${ }^{6}$ que comprime as remunerações do trabalho. Paralelamente, a estreiteza do mercado consumidor (resultante desse perfil distributivo), historicamente, impõe dificuldades para o prosseguimento da expansão do sistema produtivo no país, comprimindo a relação produto-capital, reduzindo a eficiência marginal deste fator.

Todavia, esse constrangimento técnico é contornado a partir da ação do Estado, que orienta a estrutura distributiva da renda no país, em favor da classe responsável pela demanda de bens de maior valor agregado; e das firmas internacionais que respondem por esses setores mais dinâmicos, face à dificuldade de formação de capital na economia interna. As bases que sustentam o modelo

(6) A industrialização brasileira por substituição de importações exigiu uma revolução nas técnicas produtivas (e, por conseguinte, na produtividade) na agricultura do país que, por sua vez, provocou um rápido e intenso êxodo rural (principalmente nas décadas de 1960 e 1970), que transpôs para as áreas urbanas expressiva parte da população ligada ao setor de subsistência rural, "urbanizando-o" ao ampliar o setor de subsistência das áreas urbanas. Na seção seguinte retornaremos a essa questão. 
encontram-se na existência e persistência de um setor de subsistência que garante o processo de exploração dos trabalhadores e, por conseguinte, de obtenção de elevados mark-ups. O crescimento nestes termos não se contrapõe à elevada concentração da renda (Oliveira; Nascimento, 2019).

Por fim, atenção substancial é conferida, nesta análise, aos elementos histórico-estruturais que, conjuntamente às transformações no plano internacional, processam uma articulação viciosa entre dependência externa e exploração interna, dando origem às malformações mais relevantes do subdesenvolvimento brasileiro. Neste quadro, indubitavelmente, a configuração do mercado de trabalho - analisado à luz da estrutura fundiária altamente concentrada, e da incorporação subsequente de uma tecnologia inadequada ao (e ao mesmo tempo influenciando o) desenvolvimento das forças produtivas do país ${ }^{7}$ - revela-se condicionante sine qua non para apreensão da dinâmica altamente concentradora de renda, a que o modelo de crescimento e desenvolvimento econômico faz jus.

\section{Aspectos gerais da conformação do mercado de trabalho assalariado no Brasil: as raízes da heterogeneidade social}

A gênese de um mercado de trabalho assalariado, do ponto de vista econômico, depende de modo inexorável do processo de expropriação das massas de outras vias de sustento da própria sobrevivência e, desse modo, guarda relação direta com a propriedade privada dos meios e instrumentos de produção, sendo a terra o principal. Dada a importância que este elemento historicamente assume no Brasil, a constituição do regime assalariado foi fortemente condicionada pela promulgação da Lei de Terras de 1850.

Mas, no plano cultural, há transformações que devem ser processadas também no sentido de propiciar a "disposição" para que os homens ofereçam sua força de trabalho em troca de um salário, especialmente, numa sociedade secularmente escravista, na qual "trabalhar" implica em degradação, denotando condição humilhante. Essa talvez seja uma das particularidades que mais merecem ênfase no processo de gênese do mercado de trabalho no Brasil (juntamente com todas as especificidades estruturais e instituições que remontam ao processo colonizador): a persistência histórica do modo de produção escravagista voltado para atendimento da grande empresa agrícola. A sociedade brasileira foi secularmente constituída por um grupo substancial de indivíduos que não conheciam o trabalho, a não ser pela noção demeritória que o sistema escravocrata naturalmente denotava, e é no âmbito desse quadro complexo que a formação de uma força assalariada precisaria se processar (Delgado, 2012; Kowarick, 1994).

Às vésperas da extinção do tráfico negreiro, o problema da mão-de-obra no Brasil era grave e urgente, ainda que, paradoxalmente, se dispusesse de um amplo estrato da população de livres e

(7) Embora tenha sido apresentada anteriormente a ideia básica que está implícita nessa última consideração, vale a pena reiterar, em outras palavras, que a mesma se refere à tese furtadiana na qual a "dialética inovação-difusão das técnicas" (Furtado, 1980, 2000[1967]) encontra-se condicionada pela (e condicionante da) estrutura social. No caso brasileiro, ao organizar o Plano Trienal, Furtado (2011 [1962]) propôs reformas de base para, entre outras razões, ajustar a estrutura social e produtiva em geral às novas tecnologias incorporadas pelo esforço de industrialização do Plano de Metas (a fim de, por meio de tal ajuste, facilitar a promoção do efetivo desenvolvimento do país).

Entre as quatro reformas de base propostas, as que se destinavam "à eliminação de entraves institucionais à utilização ótima dos fatores de produção" (p. 424) eram as que mais diretamente interessam à problemática do presente artigo, ou seja, a reforma fiscal/tributária e a reforma agrária. 
pobres no país compondo a denominada "economia de subsistência". Em "Formação Econômica do Brasil", Furtado se refere a essa "reserva potencial de força de trabalho" elencando duas situações: a primeira, na qual esses indivíduos viviam a partir do sustento na própria roça, utilizando-se de técnicas extremamente rudimentares, e ligavam-se, em especial, a unidades maiores, de grandes proprietários, executando, quando conviesse a estes, algum favor em troca de alguma compensação econômica. A segunda, na qual se encontravam amontoados nas zonas urbanas, oferecendo seu trabalho muito ocasionalmente e sem qualquer vinculação efetiva (Furtado, 2007 [1959]).

Com respeito à primeira situação, o autor aponta a dificuldade de atrair, reunir e organizar essa mão-de-obra para a grande lavoura, e, sobre a segunda, ele enfatiza as "dificuldades de adaptação à disciplina do trabalho agrícola". Em todo caso, essas situações corroboraram, na percepção do autor, a compreensão comum de que o "elemento nacional" não se adequava às exigências do trabalho nas lavouras (Furtado, 2007 [1959], p. 179)

Enquanto Furtado aponta como cerne da problemática ligada à incorporação dessa população livre ao mercado de trabalho a dificuldade de adaptação às condições de vida na lavoura, as quais exigiam grande disciplina, Lúcio Kowarick, por sua vez, é mais enfático na caracterização do processo valorativo em torno do referencial de trabalho, revelando maior crítica, nesse aspecto, com relação à elevada exploração e degradação associadas a este - visto que o regime que historicamente se conhecia no país era o compulsório. Portanto, nada mais natural que, na visão deste autor, a resistência dessa massa à absorção pelo trabalho nas grandes fazendas.

Conforme explicitado na passagem acima, o marco referencial do trabalho foi contaminado pelas relações do sistema escravista, predominando, tanto do ponto de vista dos homens livres e pobres, como do proprietário de terras, a ideia de exploração do indivíduo até o limite da sobrevivência. Em vista disso, aqueles que constituíam a massa amorfa da população não tinham qualquer pré-disposição à submissão ao trabalho assalariado. E, por outro lado, os produtores que também não conheciam outra noção que não a colocada pelo sistema escravocrata, viam com "maus olhos" os homens livres que se esquivavam da incorporação ao processo produtivo, caracterizandoos como vadios e imprestáveis. Em vista disso, a formação desse mercado resultaria da importação de mão-de-obra estrangeira e da constante deterioração da imagem do indivíduo brasileiro na condição de ofertante de sua força de trabalho.

Com o influxo de mão de obra estrangeira, de um lado, e a crescente massa de marginalizados do sistema econômico, constituída pelos homens pobres e livres no país, de outro, forja-se, então, um reservatório expressivo de braços potenciais para o trabalho. A constituição do regime assalariado no Brasil guarda relação inequívoca com a conformação de um "exército de reserva" que, dentre outros fins, assegurou as condições necessárias à acumulação produtiva nessa sociedade, garantindo compressão persistente dos salários e reprodução indiscriminada de uma estrutura distributiva de renda altamente desigual e concentrada (Kowarick, 1994).

Quando a derrocada do sistema escravagista se torna irreversível, a solução encontrada como forma de se evitar a recorrência ao "elemento nacional" reside, conforme já adiantado, na imigração europeia. Deve-se acentuar sobre esta última, que sua utilização tanto inicialmente com as tentativas de parceria ou regime de colonato, quanto posteriormente a partir de autêntico assalariamento, denota essencialmente o mesmo tipo de tratamento concedido ao trabalho compulsório, no sentido de que 
reforça o histórico sistema de exploração por meio de vias aparentemente distintas. Isso porque o endividamento a que os imigrantes destinados aos cafezais eram submetidos, em função de sua vinda, a cobrança de impostos e taxas abusivas, o preço dos alimentos cobrados pelos proprietários das fazendas, e outros expedientes de espoliação, corroboravam para qualificá-los como uma nova espécie de "escravos" (Barbosa, 2003; Furtado, 2007 [1959]).

Assim, além da massa de homens livres que foi se constituindo à deriva dos cafezais e se avolumando na conformação da "ralé brasileira" (Souza, 2017) o influxo de imigrantes ao final do século XIX e início do XX contribuiu de modo decisivo para a determinação e manutenção das baixas remunerações no país, mitigando o poder de barganha do trabalhador e elevando sobremodo as margens do empresariado (Kowarick, 1994). De início, a imigração de trabalhadores europeus foi o que fundamentalmente inflou a oferta de mão de obra, contribuindo para a compressão dos salários; porém, com o tempo, a expansão do processo de acumulação produtiva que propicia a industrialização por substituição de importações faria premente a necessidade de se recorrer também ao "elemento nacional" e, este, passando a compor efetivamente a força de trabalho livre, sustentaria, por conseguinte, a condição de exército de reserva. Inicialmente voltados para a vida errante ou para qualquer tipo de atividade que lhes permitisse a própria subsistência no campo, em geral, nas zonas rurais, esses potenciais trabalhadores afluem destas para as zonas urbanas, compondo vasto cerco de marginalizados e subempregados.

Esse conjunto da população compõe o que se pode denominar por setor de subsistência, representado por pessoas nas condições de informalidade, mendicância ou subemprego. Ao contrário do que, a priori, se poderia imaginar, essa massa de excluídos das relações sociais de trabalho tipicamente capitalistas exerce papel essencial dentro desse sistema. É o que aponta Barbosa (2003) ao relatar a importância estratégica desse grupo de marginalizados para o processo de acumulação de capital no Brasil.

De modo semelhante, Kowarick já pensava o problema do desenvolvimentosubdesenvolvimento neste marco: tendo por cerne a marginalização de parte expressiva da sociedade brasileira como condicionante fundamental do processo de acumulação (Leão et al., 2017). Para Kowarick, a sociedade que se constitui às margens do sistema capitalista de produção deve ser apreendida pela forma como se insere no sistema produtivo, e não pelas condições de vida que possui. O trabalhador marginal caracteriza-se por estar ligado a unidades produtivas não totalmente capitalistas, com relações de produção que não podem ser tipicamente definidas como de assalariamento (Kowarick, 1975).

Essa percepção de Kowarick situa-se relativamente próxima da que Furtado compreendia por setor de subsistência no início de seu legado intelectual. Antes do esgotamento do processo de industrialização por substituição de importações, ao abordar o conceito recorrentemente trabalhado em sua obra, Furtado parece ligá-lo às atividades de modo de produção arcaico, de cunho "nãocapitalista", deste modo, destituídas da noção de assalariamento (Furtado, 2007 [1959]).

Contudo, em "Análise do Modelo Brasileiro", obra que remonta a 1972, Furtado já apresenta indícios do reconhecimento do setor numa perspectiva distinta, mais abrangente no que diz respeito às suas características fundamentais (antes dimensionada predominantemente na agricultura e pecuária): “[...] desta forma, ter-se-ia conciliado a política de concentração da renda com a de 
expansão da massa salarial, mediante o controle da transferência de mão-de-obra dos setores desprivilegiados para aqueles protegidos pela legislação social” (Furtado, 1972, p. 39, grifos nossos).

A partir de então, o autor passa a se utilizar da noção de institucionalidade da atividade para caracterização do setor em questão (o que o diferencia da visão apresentada por Kowarick). Sua abordagem, nesse sentido, é menos enfática quanto à noção de rural ou urbano, ou mesmo em relação à questão da produtividade e do perfil tipicamente capitalista ou não presente nas atividades. Sua análise desse grupo se concentra muito mais nas condições do trabalhador de um modo geral, enfocando fatores como seguridade. Furtado (1972) menciona o trabalho de Edmar Bacha para compreensão do custo social do trabalhador, tratando, novamente, da questão dos diferenciais de salário médio real e o custo de oportunidade do trabalhador.

Bacha (1971), por sua vez, apreende o termo no contexto da marginalização, por conseguinte, de uma situação de subemprego, de tal modo que a ocupação do indivíduo nesta condição lhe proporcione um rendimento e, dessa forma, um nível de consumo, socialmente inferiores aos níveis mínimos aceitos pela sociedade no período em questão. Em termos concretos, o autor o relaciona à taxa de salário-mínimo acrescida de benefícios do seguro social e outros de denominação pública.

Tendo por base a noção de que as atividades de subsistência extrapolam a técnica ou ambiente (rural ou urbano) em que se inserem, Delgado (2004) apresenta uma concepção alinhada à do parágrafo anterior alertando para a imprescindibilidade de se reconhecer a sobrevivência do setor de subsistência no país, a qual, em sua configuração contemporânea, não é somente atestada pelas atividades não-remuneradas no campo, mas, sobretudo, pelo crescente subemprego nas zonas urbanas.

Conquanto distinto do setor de subsistência rural, o trabalho informal urbano [...] somado ao setor de subsistência rural, alarga sua dimensão ocupacional à medida que a economia entra em relativo declínio após 1981 (...) No ano 2000, o perfil ocupacional dessa nova PEA era completamente distinto. Apenas 43,1\% mantiveram-se no setor formal (contra 55,6\%, em 1980), enquanto 54,4\% estavam albergados nesse setor de subsistência mesclado pela informalidade urbana (Delgado, 2004, p. 25-26).

O texto de Delgado que propicia uma análise dos anos finais do século XX, bem como do primeiro ano do século XXI, evidencia a persistência desse setor limiar que delineia as condições do mercado de trabalho no país, servindo à função de "exército de reserva", impactando na compressão do poder de barganha dos trabalhadores e descolamento dos salários em relação aos ganhos de produtividade técnica. Isto quer dizer que, mesmo no pós contexto do processo de industrialização interna e de instituição de um mercado assalariado, sua heterogeneidade estrutural e especificidades históricas persistem e se fazem funcionais ao modelo de crescimento no marco do subdesenvolvimento brasileiro, ou seja, ao reproduzir a latente concentração da renda. Entre seus elementos centrais ainda se destacam a informalidade, o subemprego, a permanência da marginalização e a condição de arrocho dos salários.

O que foi descrito nesta seção, sem lugar à dúvida, traz à tona o fato de que os ganhos de produtividade técnica de que se aproveitara a economia brasileira a partir de 1930, não foram, de 
forma expressiva, socializados entre trabalhadores e proprietários de capital. O descolamento dos salários do nível de produtividade do trabalho é um fato que merece fundamental atenção no exame da constituição do mercado de trabalho brasileiro, colocando o país em uma situação sui generis, que inviabiliza o empreendimento de uma análise generalista, como muitas vezes se pretende ao se tratar de seu desenvolvimento econômico sob a ótica predominantemente voltada à apreensão da realidade particular das economias avançadas.

\section{Radiografia da estrutura distributiva da renda no Brasil: a persistência dos traços que qualificam e reproduzem o subdesenvolvimento}

A partir do arcabouço teórico delineado nas duas últimas seções, buscou-se evidenciar a natureza distributiva e particular do subdesenvolvimento brasileiro na perspectiva furtadiana, e sua fundamentação nas particularidades do mercado de trabalho, colaborando, assim, para sua visão funcional. Na presente seção, são evidenciados alguns dados da estrutura de distribuição de renda no Brasil, que atestam a atualidade da tese de Furtado com respeito ao modelo brasileiro.

O quadro geral da presente análise é delineado tanto por indicadores tradicionais de mensuração da distribuição de renda, como também a partir de elementos que paralelamente reforçam a apreensão desta última, em conformidade com as sugestões propostas por Furtado (1977), como é o caso das informações relativas à estrutura fundiária, ao mercado de trabalho, à dinâmica de consumo, etc. O objetivo é demonstrar, por meio dessas informações, que a qualificação do subdesenvolvimento brasileiro a partir das noções de exploração, desigualdade e concentração da renda, permanece atual.

Nesse sentido, inicia-se essa análise empírica pela observação dos indicadores mais comuns na mensuração da desigualdade econômica, dentre eles: o Coeficiente de Gini e o Índice de Theil. Esses dois índices variam de 0 a 1 , sendo que quanto mais próximo de zero, menos desigual tende a ser a distribuição da renda nesta sociedade, e quanto mais próximo de um, o raciocínio oposto se aplica. O Gráfico 1 apresenta a evolução desses indicadores no período de 1976 a 2014.

Gráfico 1

Evolução do Índice de Theil e Coeficiente de Gini no Brasil - 1976-2014

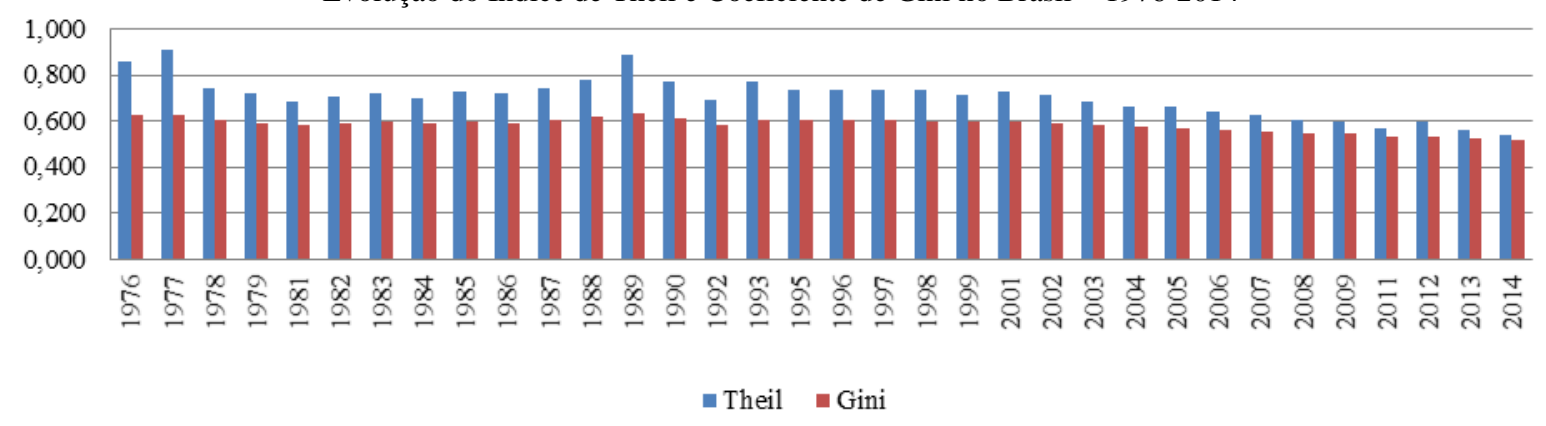

Fonte: Elaboração dos autores a partir de dados disponibilizados pelo Ipeadata (com base nos microdados das PNADs/IBGE).

O Índice de Theil atingiu 0,912 em 1977, ano em que se revelou mais elevado, e 0,541 em 2014, ano em que chegou ao seu nível mais baixo. Somente a partir de 2009 é que o índice chegou à 
casa de 0,5. Já o coeficiente de Gini registrou patamares menores relativamente ao Índice de Theil. Em 1989 ocorreu seu maior pico para a renda, no valor de 0,636, e em 2014 seu menor número, 0,518. Sua tendência continuamente decrescente registrou-se a partir do ano 2001. Pode-se observar, portanto, uma relativa melhora dos indicadores de Theil e Gini, embora continuem elevados, ambos acima de 0,5 .

Além disso, e ainda com base nos microdados da PNAD, enfocando-se a parcela da renda nacional que é apropriada pelo $1 \%$ mais rico, comparativamente aos 50\% mais pobres, obtém-se uma das amostras mais expressivas da desigualdade no Brasil: o $1 \%$ respondeu, em média, por quase $14 \%$ da renda nacional, mesmo percentual apropriado pelos 50\% mais pobres no interregno 1977-2014 (Gráfico 2). Todavia, é possível notar uma ligeira tendência de redução da participação dos primeiros, ao mesmo tempo em que se eleva a participação desses últimos.

Gráfico 2

Parcela da renda nacional apropriada por decis de renda no Brasil - 1977-2014 (\%)

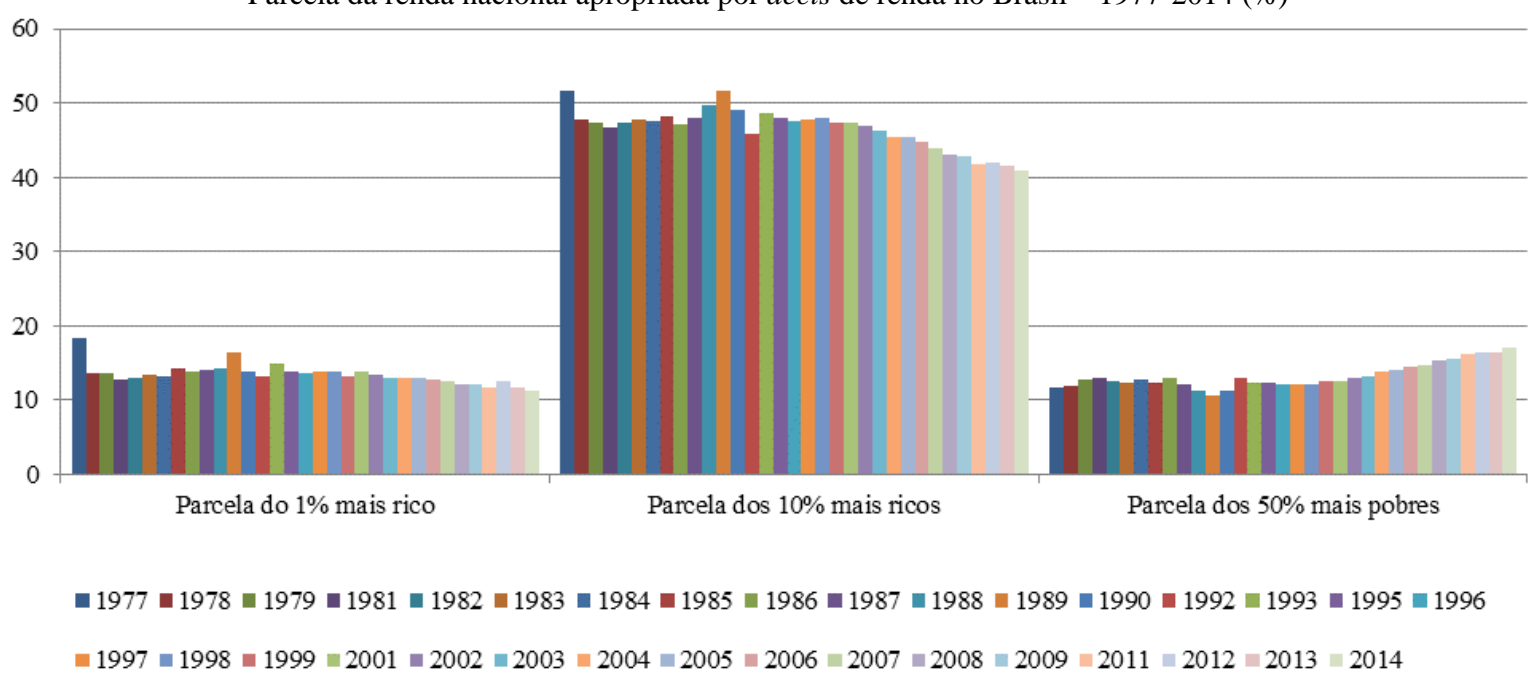

Fonte: Elaboração dos autores a partir dos dados disponibilizados pelo Ipeadata (com base nos microdados das PNADs/IBGE).

Apesar do que indicam os microdados da PNAD, importa chamar atenção para a forte tendência à subdeclaração de rendimentos (especialmente entre os declarantes das maiores rendas), bem como para a existência de limitações inerentes à própria amostragem e desenho dos questionários. Desse modo, é possível estar diante de constatação tendenciosa acerca da redução da desigualdade no país, se sustentados apenas por essa base (Hoffmann, 1988; Medeiros; Souza; Castro, 2015; Morgan, 2018). Em vista disso, os dados tributários podem oferecer uma importante perspectiva adicional para esta análise.

Os dados das Declarações do Imposto de Renda da Pessoa Física (DIRPF) no Brasil revelam um cenário menos favorável acerca da recente tendência de redução da desigualdade de renda no país. Por meio deles, verifica-se que a parcela da renda fiscal do $1 \%$ mais rico evidencia um incremento no período 2001-2015. Ainda assim, a fatia que correspondeu aos 50\% mais pobres se elevou, tendo sido de $12,63 \%$ no primeiro ano e 13,88 no último (Gráfico 3 ). 
Gráfico 3

Parcela da renda fiscal apropriada pelo $1 \%$ mais rico, $10 \%$ mais ricos, $40 \%$ medianos e $50 \%$ mais pobres no Brasil 2001-2015 (\%)

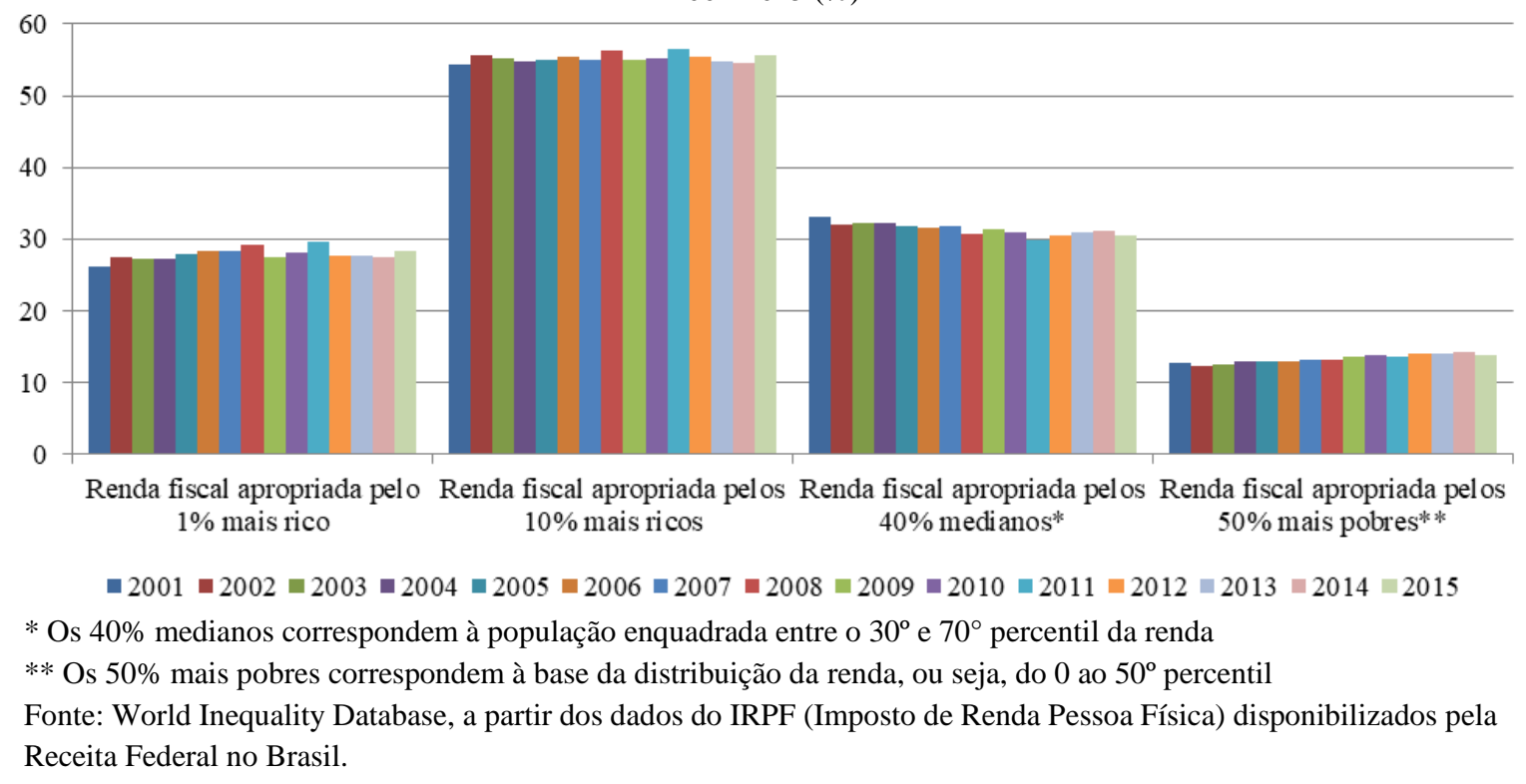

Por outro lado, do ponto de vista da comparação da concentração da renda em mãos do $1 \%$ mais rico no Brasil relativamente à de outros países, o Gráfico 4 apresenta a parcela da renda apropriada por esse grupo em diversas economias, no ano de 2002. O Brasil foi o país que apresentou o maior percentual de renda concentrado pelo grupo em questão (27\%) relativamente aos demais países analisados. Observe-se que depois da Rússia - país que mais se aproximou do Brasil em desigualdade de renda fiscal - a grande maioria dos países se encontrava em uma situação bastante menos desigual do que o Brasil.

Gráfico 4

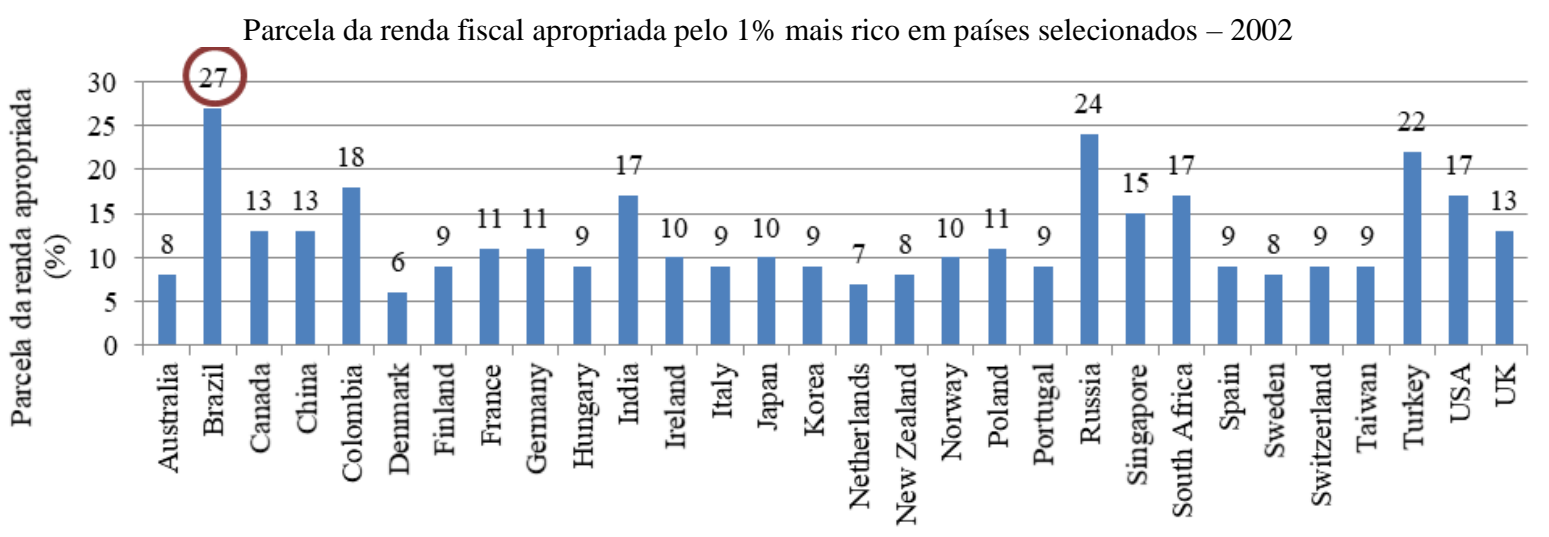

Fonte: World Inequality Database.

Em 2010, o Brasil ainda continuava com o maior percentual de apropriação da renda pelo grupo do $1 \%$ mais rico do país, entre as economias selecionadas, ressaltando sua elevação para $28 \%$. 
Portanto, embora a distribuição da renda fiscal tenha melhorado um pouco (Gráfico 3), os Gráficos 4 e 5 revelam que a concentração ainda é expressivamente alta no Brasil, comparativamente a vários outros países.

Gráfico 5

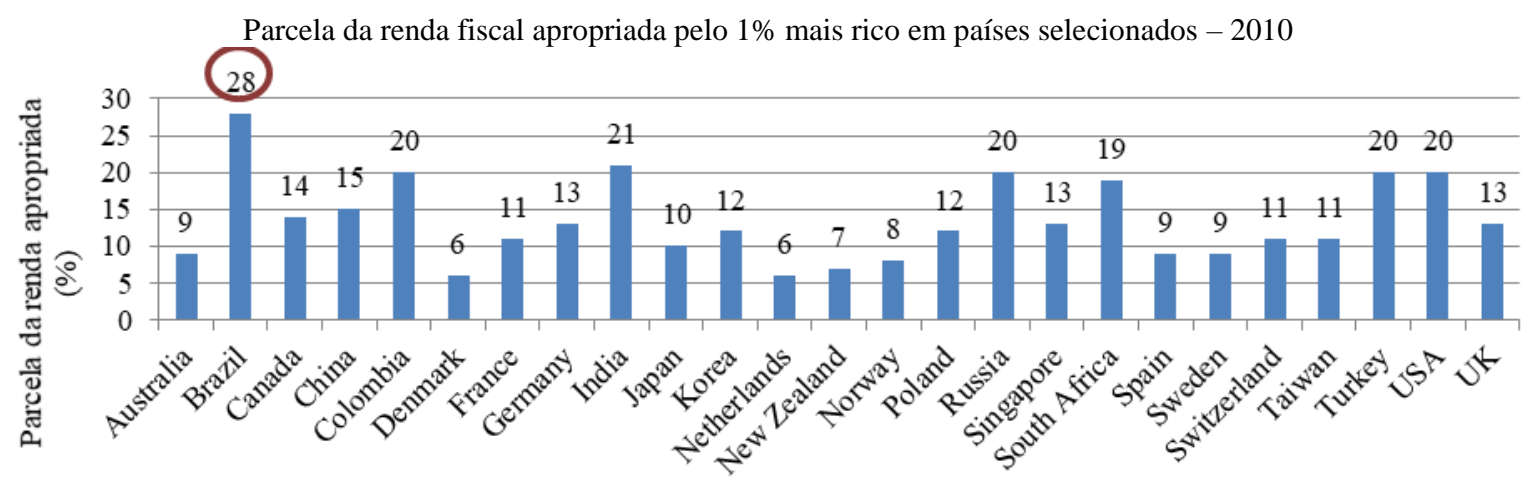

Fonte: World Inequality Database.

Diante de tão elevada concentração da renda pelo grupo constituído pelo $99^{\circ}$ percentil, um tema notadamente pertinente na análise da estrutura distributiva diz respeito ao sistema de tributação de rendimentos. No Brasil, a natureza regressiva do sistema tributário guarda correspondência inequívoca com sua heterogeneidade socioeconômica. Para além do fato de que o país prima pela taxação indireta, primordialmente sobre consumo, vis-à-vis a riqueza e renda, a tributação sobre os rendimentos da pessoa física apresenta um tratamento diferenciado relativamente às rendas do capital, de tal modo que a elite do país (constituída, sobretudo, por grandes proprietários de capital) acaba isenta sobre parte expressiva de seus rendimentos.

Morgan (2018) analisa o tema da taxação de impostos sobre a elite no Brasil e a progressividade do imposto sobre a renda de pessoas físicas. Com relação ao aspecto da equidade horizontal (extensão na qual todas as fontes de rendimento são tributadas de forma isonômica), o sistema de tributação de rendimentos no país viola esse princípio, tendo em vista que nem todas as fontes de renda são taxadas com referência numa mesma tabela, a exemplo dos ganhos de capital sobre os quais incidem alíquotas exclusivas que variam de $15,0 \%$ a $22,5 \%$.

Há três categorias de rendimentos legais no Brasil, para os fins da DIRPF: a renda tributável, que inclui salários, pensões, aluguéis, etc.; os rendimentos retidos tributáveis, como os ganhos de capital, juros sobre investimentos financeiros, entre outros; e os não tributáveis que dizem respeito à distribuição de lucros e dividendos, indenizações, etc. Ressalta-se que o Brasil é um dos pouquíssimos países no mundo cujos lucros e dividendos são isentos de tributação (Fagnani; Rossi, 2018). Segundo Gobetti e Orair (2016) uma das maiores distorções do sistema tributário brasileiro refere-se a esse tratamento diferenciado que é concedido à renda do capital.

Analisando como se distribuem os rendimentos da elite no Brasil, com base nos dados da DIRPF, verifica-se que quanto mais elevado o percentil de renda correspondente aos indivíduos, maior tende a ser a proporção da renda não tributável. Por exemplo, no 99,99 de renda, (onde temos o $0,01 \%$ mais rico), o percentual da renda tributável é de aproximadamente $10 \%$ e aproximadamente $50 \%$ é isenta de tributação (Morgan, 2018). 
No que diz respeito à equidade vertical do sistema tributário brasileiro (extensão na qual os indivíduos com rendas mais elevadas respondem por frações maiores de tributação), Morgan (2018) ressalta outra violação, já que, quanto mais elevado o percentil da renda do indivíduo, menor o percentual médio efetivo de taxação da renda. As alíquotas médias de imposto começam a cair especialmente para além do $99,5^{\circ}$ percentil, ou seja, no âmbito do $0,5 \%$ mais rico do país.

Introíni et al. (2018) apontam para o fato de que no Brasil, a partir da faixa de 30 a 40 saláriosmínimos, as alíquotas médias efetivas diminuem à medida que a renda aumenta. Segundo os autores, a diferenciação no tratamento à renda do capital resulta em alíquotas efetivas médias menores para os contribuintes com altos rendimentos. Em 2016, por exemplo, com base nos dados da DIRPF, eles calcularam que a maior alíquota efetiva média correspondeu a $11,8 \%$, na faixa de 30 a 40 saláriosmínimos de rendimento mensal (Gráfico 6).

Gráfico 6

Alíquota efetiva média do IRPF por faixas de renda mensal em salários-mínimos (\%)

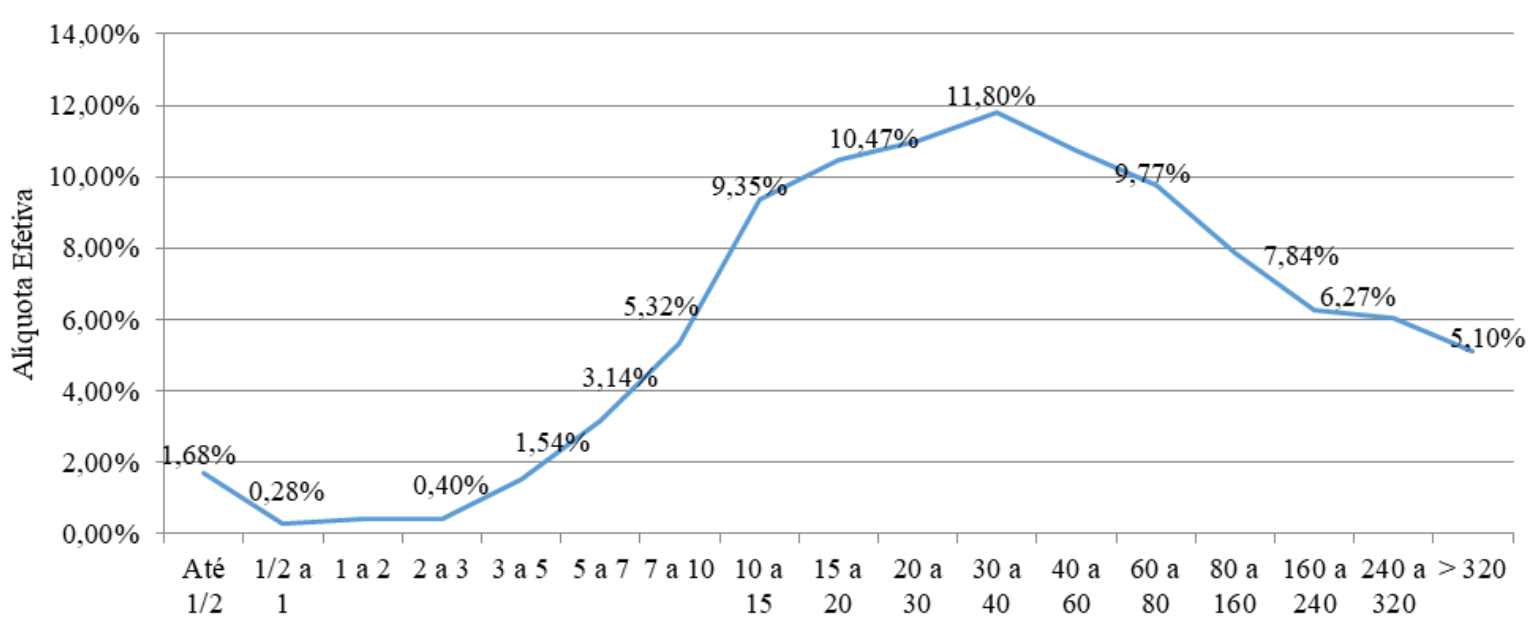

Fonte: Introíni et al. (2018, p. 272).

A desoneração das rendas do capital no Brasil se dá particularmente por meio de dois instrumentos: a isenção dos lucros e dividendos aos sócios e acionistas, conforme já mencionado anteriormente, e a previsão de dedução de "juros sobre o capital próprio". Desse modo, o próprio desenho do sistema tributário brasileiro torna-o mecanismo eficaz de reprodução do histórico processo de concentração da riqueza e renda no país.

Essas informações indubitavelmente parecem confirmar a importância diminuta da tributação sobre rendimentos como instrumento de justiça fiscal no Brasil, por conseguinte, a ineficácia desse sistema para a promoção da redução da desigualdade econômico-social no país. Ao contrário, da forma como o sistema tributário encontra-se delineado, ele se torna um mecanismo eficaz de reprodução da imutável estrutura de concentração da riqueza e renda na sociedade brasileira.

No que respeita à estrutura de propriedade da terra no Brasil, dentre as suas principais características, encontra-se a inalterável predominância do latifúndio, improdutivo ou voltado ao agronegócio exportador. A modernização da agricultura e o novo contexto de capital financeirizado 
e oligopolizado acrescem à questão elementos ainda mais complexos para a operacionalização de uma reforma, dadas as correlações de forças existentes.

Os dados do levantamento que é realizado pelo DATALUTA ${ }^{8}$ fornecem uma visão da estrutura fundiária no Brasil, a partir de anos que não são contemplados pelo Censo Agropecuário. Por meio deles é possível notar que, entre 1998 e 2014, cerca de 2,5 milhões de imóveis rurais foram acrescidos à estrutura fundiária brasileira. $\mathrm{O}$ crescimento é expressivo, tanto em termos absolutos quanto em percentuais, dos imóveis na primeira faixa - de menos de cinco hectares.

Por sua vez, o Censo Agropecuário 2017, recentemente divulgado, registra outro aumento no número de estabelecimentos rurais com menos de cinco hectares de área. Enquanto as informações do DATALUTA (Tabela 4) informam que a participação desse grupo no total de estabelecimentos rurais correspondia a 21,17\%, em 2014, o Censo Agropecuário confirma um aumento dessa participação em 16,15 p.p., chegando a 37,31\%, em 2017.

Adicionalmente, a Tabela 1 informa que, a despeito do largo predomínio e da tendência de aumento da participação relativa dos estabelecimentos menores (menos de 5ha), esse grupo permanece com apenas $1,0 \%$ de toda a área do total de estabelecimentos. Mesmo considerando o conjunto de estabelecimentos com a até 10 hectares, constata-se que 50,9\% dos estabelecimentos totais detinham tão somente $2,3 \%$ de toda a área. Na outra ponta, considerando os estabelecimentos com 1.000 hectares ou mais, verifica-se que esse pequeníssimo grupo concentrava $47,6 \%$ de toda a área agrícola, em 2017. Ou seja, a profunda assimetria de poder que mantém a sociedade brasileira presa ao subdesenvolvimento reflete a também profunda desigualdade da distribuição da propriedade da terra revelada nessas informações (Tabela 1).

Tabela 1

Distribuição absoluta e percentual do número e da área de estabelecimentos rurais, segundo faixas de tamanho de área, em hectares: Brasil, 2017 (números absolutos em milhares)

\begin{tabular}{|c|c|c|c|c|c|c|c|c|c|c|}
\hline \multirow{3}{*}{$\begin{array}{c}\text { Classes de Área } \\
\text { (ha) }\end{array}$} & \multicolumn{6}{|c|}{ DATALUTA } & \multicolumn{4}{|c|}{ Censo Agropecuário 2017} \\
\hline & \multirow[t]{2}{*}{1998} & \multirow[t]{2}{*}{2003} & \multirow[t]{2}{*}{2010} & \multirow[t]{2}{*}{2014} & \multicolumn{2}{|c|}{ Var.\% 1998/2014 } & \multicolumn{2}{|c|}{$\begin{array}{c}\text { Número de } \\
\text { estabelecimentos } \\
\text { agropecuários (2017) }\end{array}$} & \multicolumn{2}{|c|}{$\begin{array}{c}\text { Área dos } \\
\text { estabelecimentos } \\
\text { agropecuários (2017) }\end{array}$} \\
\hline & & & & & $\begin{array}{c}\mathrm{N}^{\circ} \\
\text { Absol. }\end{array}$ & (Var.\%) & Unidades & $\begin{array}{l}\% \text { s/o } \\
\text { Total }\end{array}$ & $\begin{array}{c}\text { Em } \\
\text { Hectares }\end{array}$ & $\%$ s/ o Total \\
\hline Menos de 5 (ha) & 628 & 783 & 972 & 1.300 & 671 & 106,9 & 1.893 & 37,9 & 3.425 & 1,0 \\
\hline $5 \mathrm{a}<\mathrm{de} 10$ & 516 & 626 & 773 & 909 & 393 & 76,2 & 651 & 13,0 & 4.569 & 1,3 \\
\hline $10 \mathrm{a}<\mathrm{de} 50$ & 1.513 & 1.803 & 2.130 & 2.432 & 919 & 60,8 & 1.587 & 31,8 & 36.868 & 10,5 \\
\hline $50 \mathrm{a}<\mathrm{de} 100$ & 404 & 486 & 579 & 666 & 262 & 65,0 & 394 & 7,9 & 26.943 & 7,7 \\
\hline $100 \mathrm{a}<\mathrm{de} 500$ & 406 & 454 & 563 & 646 & 240 & 59,1 & 366 & 7,3 & 74.256 & 21,1 \\
\hline $500 \mathrm{a}<$ de 1.000 & 63 & 69 & 85 & 94 & 31 & 49,5 & 55 & 1,1 & 38.002 & 10,8 \\
\hline $\begin{array}{l}1.000 \mathrm{a}<\mathrm{de} \\
10.000\end{array}$ & 55 & 67 & 77 & 92 & 37 & 66,6 & 49 & 1,0 & 115.582 & 32,9 \\
\hline 10.000 a mais & 3 & 1 & 2 & 3 & 0 & 14,2 & 2 & 0,05 & 51.645 & 14,7 \\
\hline Total & 3.587 & 4.291 & 5.182 & 6.140 & 2.554 & 71,2 & 4.996 & 100,0 & 351.290 & 100,0 \\
\hline
\end{tabular}

Fonte: Elaboração dos autores a partir dados do DATALUTA e do IBGE - Censo Agropecuário 2017.

(8) Banco de dados da Luta pela Terra derivado de um projeto de extensão e pesquisa do Núcleo de Estudos, Pesquisas e Projetos de Reforma Agrária (NERA) da Universidade Estadual Paulista (UNESP). 
A Tabela 2 reforça a constatação da aguda e persistente concentração e desigualdade de distribuição de terras no Brasil. O Índice de Gini da Terra exibiu relativa estabilidade em torno de 0,850 no período analisado. O Índice de Atkinson, por sua vez, revelou uma tendência de crescimento, o que pode ser atribuído à sua forma de mensuração que permite captar modificações na estrutura distributiva da cauda inferior da distribuição dos dados (Hoffmann; Ney, 2003; 2010). Adicionalmente, nota-se a redução do percentual da área ocupada pelas 50\% menores propriedades e, em contrapartida, uma elevação da parcela que corresponde aos $5 \%$ maiores.

Tabela 2

Desigualdade da estrutura fundiária no Brasil, 1975, 1980, 1985, 1995, e 2006

\begin{tabular}{l|c|c|c|c}
\hline Ano & Índice de Gini & Índice de Atkinson & $\begin{array}{c}\% \text { da área ocupada } \\
\text { pelos 50\% menores }\end{array}$ & $\begin{array}{c}\% \text { da área ocupada } \\
\text { pelos 5\% maiores }\end{array}$ \\
\hline 1975 & 0,855 & 0,856 & 2,5 & 68,7 \\
\hline 1980 & 0,857 & 0,860 & 2,4 & 69,3 \\
\hline 1985 & 0,858 & 0,865 & 2,3 & 69,0 \\
\hline $1995 / 1996$ & 0,857 & 0,867 & 2,3 & 68,8 \\
\hline
\end{tabular}

Fonte: Elaboração dos autores a partir de dados do Censo Agropecuário - Séries temporais / IBGE-SIDRA.

Esse conjunto de dados delata a persistência da concentração da renda no Brasil por meio de uma estrutura fundiária extremamente desigual. A alienação de parte importante da massa da população do acesso à terra tem impactos variados e profundos sobre o desenvolvimento do país, refletindo-se especialmente em elementos como o nível de produtividade geral, nos preços dos principais alimentos necessários à subsistência, na magnitude da pobreza, na configuração do mercado de trabalho, incluindo os rendimentos dos trabalhadores e, por conseguinte, na distribuição da renda e riqueza no país. A dimensão particular desta análise denuncia, portanto, uma das formas sob as quais a exploração interna das massas pode continuar indefinidamente, caso se prossiga sem empreendimento de uma efetiva reforma ${ }^{9}$.

Outro plano, cuja dinâmica invariavelmente expressa a (e também decorre da) concentração e desigualdade da renda, diz respeito ao consumo. No Brasil os dados sobre consumo podem ser analisados a partir das informações da Pesquisa de Orçamentos Familiares (POF) realizada pelo Instituto Brasileiro de Geografia e Estatística (IBGE). Em face de aspectos metodológicos, serão apresentados alguns dados referentes às POFs de 2002-2003 e de 2008-200910.

(9) Em um esforço de demonstrar empiricamente que no Brasil do século XXI ainda permanece necessária a reforma agrária como forma de se resolver a ainda insolúvel questão agrária, Ramos (2014, p. 689) conclui seu estudo asseverando que “...é lamentável que alguns estudiosos limitem a importância da questão agrária apenas aos números da migração campo/cidade. Suas implicações vão muito além e é exatamente em razão disso que não se pode negar que no Brasil contemporâneo há enorme dificuldade para mudar o caráter patrimonialista, tão bem tratado na obra de Raimundo Faoro. Enfim, negar a Questão Agrária é negar que a terra ainda é uma das bases do poder e dominação econômica, política e social no País."

(10) As Pesquisas de Orçamentos Familiares dos anos 80 e 90 foram mais voltadas à atualização das estruturas de consumo dos índices de preços ao consumidor produzidos pelo IBGE, nas Regiões Metropolitanas do país. As POFs dos anos 2000, por sua vez, além de incorporarem todo o território brasileiro, adicionam temas importantes em relação às condições de vida a partir do consumo, aprofundando e expandindo as questões que vinham sendo abordadas. 
A Tabela 3 refere-se à "desigualdade funcional do consumo", retratada por meio de uma razão entre a "despesa média de consumo" dos trabalhadores e a dos empregadores. Considerando o enfoque funcional, a despesa de consumo mensal familiar foi distribuída entre as ocupações de trabalhadores e empregadores, sendo que, no caso dos primeiros, considerou-se apenas: empregados privados e públicos, e trabalhadores domésticos. Parte relevante das famílias se concentra no grupo cujo membro de referência é o empregado privado (68\% das famílias em 2002-2003 e 78\% em 2008$2009)^{11}$. O consumo destes representa, em média, cerca de $40 \%$ do consumo do empregador. O caso mais expressivo dessa razão de desigualdade se refere ao do trabalhador doméstico cujo consumo é de, aproximadamente, apenas $20 \%$ do consumo do empregador. Há uma ligeira melhora entre os dados de 2002-2003 e 2008-2009, mas que não altera essa disparidade de consumo no nível funcional.

Tabela 3

Despesa média de consumo mensal familiar no Brasil, número de famílias e razão de desigualdade do consumo, segundo posição na ocupação (apenas empregados e empregadores) - 2002-2003 e 2008-2009

\begin{tabular}{l|c|c|c|c}
\hline \multicolumn{5}{|c|}{$2002-2003$} \\
& $\begin{array}{c}\text { Empregado } \\
\text { privado }\end{array}$ & $\begin{array}{c}\text { Empregado } \\
\text { público }\end{array}$ & $\begin{array}{c}\text { Trabalhador } \\
\text { doméstico }\end{array}$ & Empregador \\
\hline Despesa média de consumo (R\$) & $1.381,72$ & $2.192,34$ & 740,35 & $3.505,45$ \\
\hline Número de famílias & 17.263 .098 & 4.107 .758 & 1.971 .490 & 1.961 .210 \\
\hline Razão de desigualdade funcional do consumo & 0,39 & 0,63 & 0,21 & 1,00 \\
\hline \multicolumn{7}{|c|}{$2008-2009$} & $\begin{array}{c}\text { Empregado } \\
\text { privado }\end{array}$ & $\begin{array}{c}\text { Empregado } \\
\text { público }\end{array}$ & $\begin{array}{c}\text { Trabalhador } \\
\text { doméstico }\end{array}$ & Empregador \\
\hline Despesa média de consumo (R\$) & 2.044 & 3.112 & 1.145 & 5.119 \\
\hline Número de famílias & 19.884 .627 & 5.093 .137 & 2.466 .034 & 1.834 .372 \\
\hline Razão de desigualdade funcional do consumo & 0,40 & 0,61 & 0,22 & 1,00 \\
\hline
\end{tabular}

Fonte: Elaboração dos autores a partir da POF-IBGE.

Gastos por setores econômicos são evidenciados pela Tabela 4. As diferenças no volume de recursos dispendidos em cada segmento impressionam especialmente em atividades como educação, transporte e ICT (Information and Communication Technology). O gasto médio per capita em educação no segmento alto foi cerca de 140 vezes o verificado no segmento muito baixo evidenciando uma dimensão da morfologia do excedente apresentada por Furtado (1977), quando o autor aponta como uma das perspectivas de análise as "desigualdades nos gastos que realizam as famílias para aumentar a eficácia dos novos membros como fator de produção" (Furtado, 1977, p. 26). Verifica-se, assim, a latente assimetria da sociedade brasileira atestada também nesta dimensão.

(11) Estes percentuais se aplicam considerando-se o somatório dessas quatro posições excluindo-se o "conta própria" e o "trabalhador para o próprio consumo ou uso". Essa opção foi feita porque na discussão acerca da desigualdade funcional da renda, ou seja, entre assalariados e detentores de capital, o trabalhador para o próprio consumo não figura como assalariado e o trabalhador por conta própria dificilmente pode ser enquadrado com precisão em uma ou em outra categoria, devido à problemática de classificação dos rendimentos dos autônomos em países subdesenvolvidos, tal como observado em Gollin (2002). 
Tabela 4

Consumo médio mensal per capita por setores e segmentos de consumo - Brasil - 2008-2009 (em R\$)

\begin{tabular}{|c|c|c|c|c|}
\hline Setor & $\begin{array}{l}\text { Muito baixo } \\
(<\$ 2.97 \text { per } \\
\text { capita/ dia) }\end{array}$ & $\begin{array}{c}\text { Baixo } \\
\text { (entre \$2.97 e } \\
\$ 8.44 \text { per } \\
\text { capita/dia) }\end{array}$ & $\begin{array}{c}\text { Médio } \\
\text { (entre } \$ 8.44 \text { e } \\
\$ 23.03 \text { per } \\
\text { capita/dia) }\end{array}$ & $\begin{array}{c}\text { Alto } \\
(>\$ 23.03 \text { per } \\
\text { capita/dia) }\end{array}$ \\
\hline Comida e bebidas & 486,28 & $1.268,44$ & $2.499,63$ & $4.395,71$ \\
\hline Roupas e calçados & 116,72 & 307,62 & 663,15 & $1.375,47$ \\
\hline Casa & 77,23 & 231,92 & 640,64 & $1.918,61$ \\
\hline Energia & 164,11 & 310,86 & 484,74 & 759,71 \\
\hline Transporte & 140,28 & 598,14 & $2.201,07$ & $9.420,02$ \\
\hline Água & 44,64 & 93,39 & 143,68 & 189,52 \\
\hline Educação & 9,85 & 56,81 & 376,3 & $1.398,48$ \\
\hline Saúde & 102,6 & 325,8 & 877,48 & $2.431,80$ \\
\hline ICT & 23,31 & 129,59 & 368,61 & 773,04 \\
\hline Serviços Financeiros & 0,37 & 2,73 & 10,21 & 22,93 \\
\hline Outros bens e serviços & 127,19 & 423,28 & $1.308,60$ & $7.958,84$ \\
\hline Eletrodom., artigos de cuidado pessoal & 35,34 & 104,01 & 210,65 & 406,65 \\
\hline
\end{tabular}

Fonte: Elaboração dos autores a partir dos dados do World Development Indicators (WDI) - Consumption Database.

A estrutura de consumo brasileira, sobretudo no que diz respeito à sua composição por estratos da sociedade, constitui um tema notadamente caro a Celso Furtado. Os dados a seguir somamse a esse conjunto de informações já apresentadas na dimensão do consumo para apreensão das especificidades estruturais da economia brasileira, especialmente de sua elevada heterogeneidade social.

Gráfico 7

Evolução do percentual (\%) dos domicílios urbanos com $\operatorname{ICBD}^{(1)}$ acima de 0,50 , segundo faixas de renda domiciliar (em salários-mínimos): Brasil, 2002 a 2015.

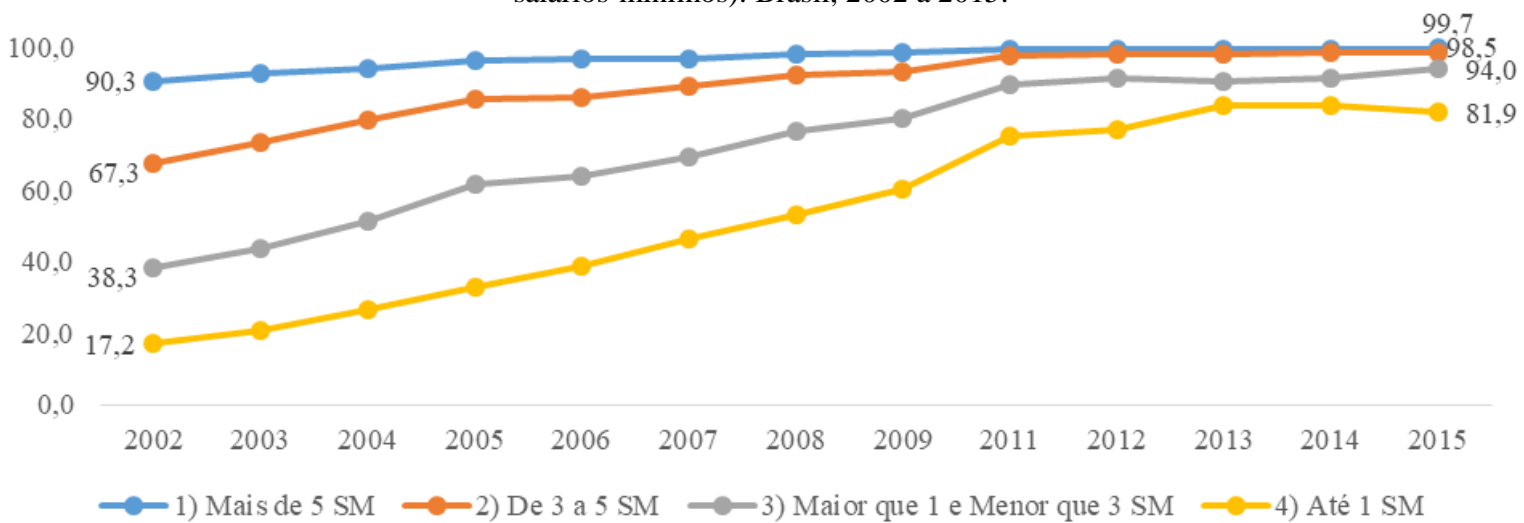

* ICBD: Indicador de Consumo de Bens Domiciliares.

(1) Criou-se um Indicador de Consumo de Bens Domiciliares - ICBD, cujo resultado consiste em uma média simples das quatro informações selecionadas (telefone celular, TV em cores, geladeira, máquina de lavar roupa), obtendo-se resultados, para cada domicílio, que variam entre 0 e 1 (ou 100\%). Quanto mais próximo de 1, melhor o resultado do indicador. Construiu-se duas faixas do ICBD: i) 0 a 0,50 (= até 2 dos 4 itens); e ii) Acima de 0,50 a 1,0 (= mais de 2 dos 4 itens). O Gráfico 7 exibe o resultado apenas para essa segunda faixa.

Fonte: Elaboração dos autores a partir dos microdados da PNAD/IBGE 
As informações registram uma ampliação relevante do mercado de massas no país, a despeito das elevadas desigualdades de renda, tendo em vista a incorporação das famílias urbanas de até 1 salário-mínimo familiar ao consumo de bens industrializados como: TV em cores, telefone celular, geladeira e máquina de lavar roupas (Gráfico 7). Por outro lado, o acesso dessas mesmas famílias/domicílios às condições ideais de saneamento, por meio de rede de esgoto ou pluvial, cresce de forma muito mais tímida, saindo de 41,2\%, no ano 2002, para 58,1\%, em 2015 (Gráfico 8). Embora este seja um aumento importante, torna-se relativamente modesto quando comparado ao verificado para o acesso aos produtos mencionados anteriormente, que, em 2002, era de $17,2 \%$ e passa a $81,9 \%$, em 2015.

\section{Gráfico 8}

Evolução do percentual (\%) dos domicílios urbanos com acesso à rede coletora de esgoto ou pluvial, segundo faixas de renda (\%) domiciliar (em salários-mínimos): Brasil, 2002 a 2015

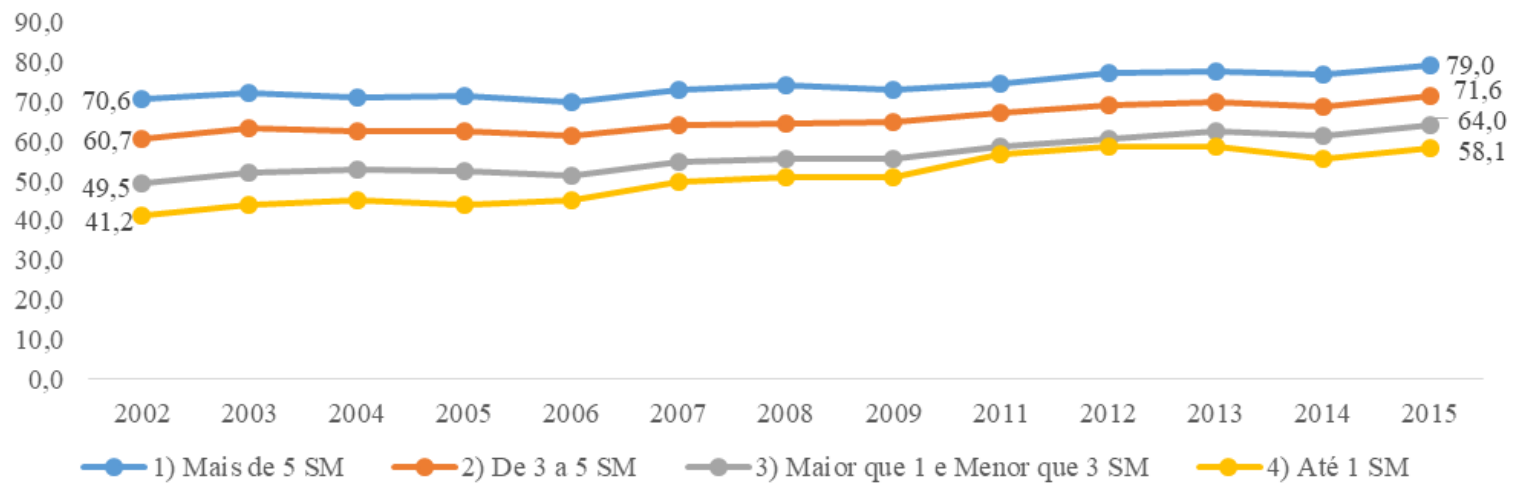

Fonte: Elaboração dos autores a partir dos microdados da PNAD/IBGE.

Percebe-se, portanto, que as famílias brasileiras experimentaram relativa massificação do consumo de bens industrializados (arquétipos das sociedades centrais) no período mais recente, ainda que questões fundamentais para a homogeneização social permaneçam sem resolução, como o caso do saneamento básico evidenciado. Carneiro (2001) já havia identificado uma dinâmica semelhante nos anos 1990. O problema dessa dinâmica é que embora o acesso das famílias de baixa renda a certos eletrodomésticos seja importante, elas ainda se encontram em certa medida privadas do acesso a serviços públicos essenciais de qualidade. O que desvela a inversão de valores no cerne da sociedade brasileira.

Outro ponto relevante nesse esforço de apresentação da estrutura distributiva brasileira diz respeito à proporção de pessoas abaixo da linha da pobreza. Esse número diminuiu consideravelmente entre 1981 e 2015, e, sobretudo, a partir da segunda metade dos anos 2000, em boa medida, como reflexo de políticas que, de forma ainda muito tímida, permitiram maior inserção da massa no sistema econômico. O Gráfico 9 exibe essa informação, segundo duas classificações da Organização das Nações Unidas (ONU): uma em U\$\$1,90 ao dia, e outra em U\$\$5,50 12 .

(12) Esta é uma tentativa da organização de captar melhor a situação de pobreza das pessoas que vivem em países subdesenvolvidos que apresentam renda per capita relativamente elevada e alto custo de vida. 
Gráfico 9

Percentual da população vivendo abaixo da linha da pobreza no Brasil, segundo duas classificações da ONU (Organização das Nações Unidas) - 1981-2015

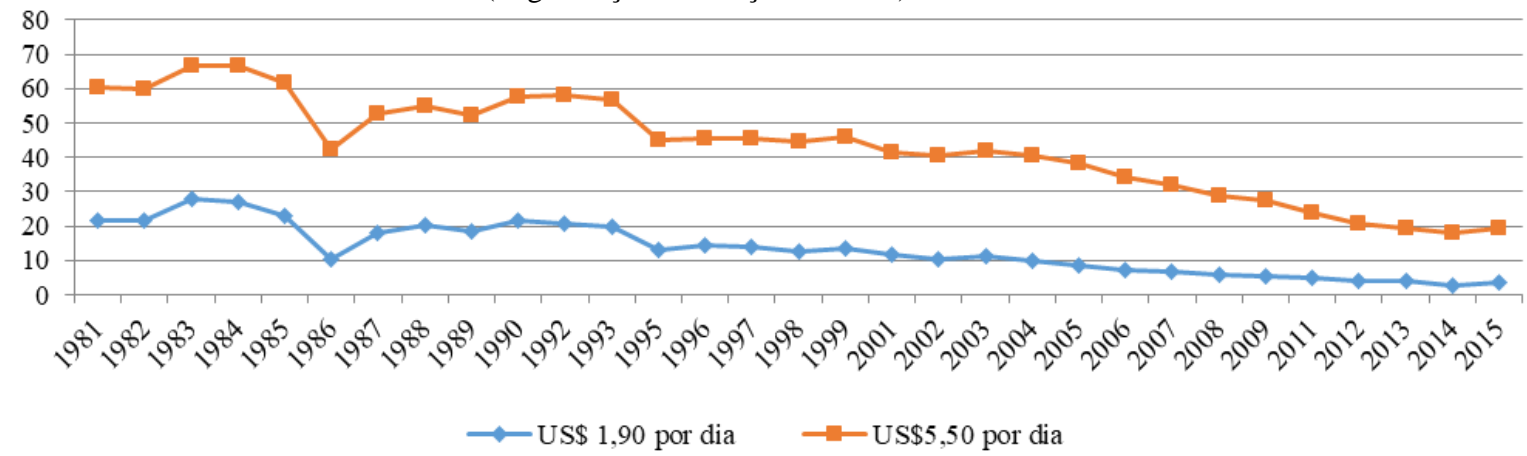

Fonte: Elaboração a partir de dados disponibilizados pelo World Development Indicators (WDI).

Nos anos 2000, muito embora não se tenha logrado resolver as questões estruturais que delineiam a dinâmica distributiva da renda no país (a exemplo da fundiária), o Governo Lula intensificou as políticas assistencialistas, bem como criou programas voltados à oferta de infraestrutura mínima aos cidadãos brasileiros, como o programa "Luz para todos". Essas medidas corroboram para redução das disparidades socioeconômicas no país, muito embora sejam insuficientes para atacar precisamente os elementos estruturais da dinâmica heterogênea e desprovida de coesão social que tipifica o subdesenvolvimento brasileiro.

De todo modo, uma medida importante referiu-se à implementação, nos anos 2000, da política de valorização do salário-mínimo reajustado pela inflação e pela taxa de crescimento do produto interno bruto. Considerando que parte expressiva da população brasileira se constitui de trabalhadores que ganham até no máximo dois salários-mínimos ${ }^{13}$, essa metodologia permitiu maior acesso das pessoas ao mercado de consumo, muito embora, conforme vimos, não tenha se revelado suficiente para reverter sua heterogeneidade elevada.

Adicionalmente, o período em questão foi marcado por redução importante do desemprego, o que, por conseguinte, implica na incorporação de mais pessoas ao sistema econômico. O Gráfico 10 apresenta as taxas de desemprego segundo a PNAD, a PME (Pesquisa Mensal do Emprego) e a taxa disponibilizada pela OECD (Organização para Cooperação e Desenvolvimento Econômico).

Analisando a evolução da taxa de desemprego por meio dos dados da PNAD, considerando, em face das questões metodológicas, apenas o interregno 1992-2014, embora seja notável o movimento decrescente do desemprego na segunda metade dos anos 2000, é possível verificar que as taxas são um pouco maiores que as verificadas pela OECD, a qual parece se basear, no período em questão, na Pesquisa Mensal do Emprego. De acordo com a PNAD, a maior taxa no período foi a do ano de $2003(10,5 \%)$, e a menor, dez anos depois, a de $2013(7,1 \%)$.

(13) Conforme os microdados da PNAD 2015, 68,3\% dos empregados obtiveram até dois salários mínimos. Esse percentual sobe para $82,0 \%$ se tomarmos em conta a faixa de até três salários mínimos. Se considerarmos conjuntamente os empregados e os trabalhadores por conta-própria, aqueles percentuais são praticamente os mesmos para cada uma das faixas de renda - 68,6\% e $81,9 \%$, respectivamente. 
Gráfico 10

Taxa de desemprego no Brasil OECD, PNAD e PME, de 1981-2014 (\%)
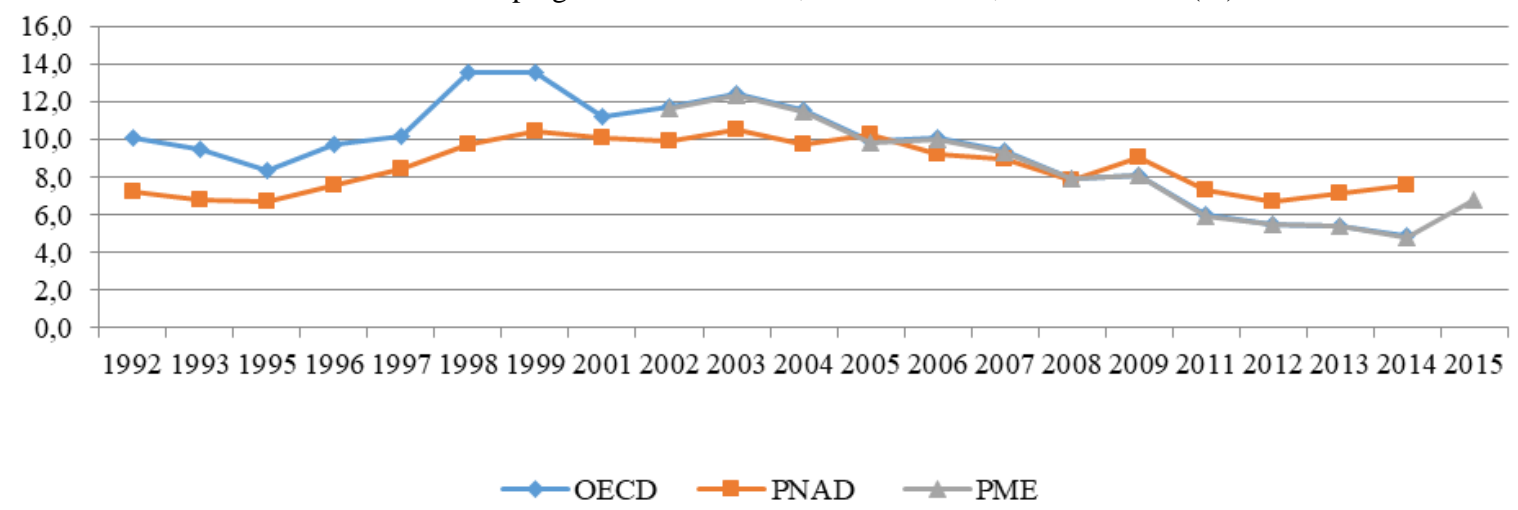

Fonte: Elaboração dos autores a partir de dados da OECDstat, PNAD-IBGE, e PME-IBGE.

Os dados da PNAD também apresentam a segmentação dos indivíduos pela posição na ocupação. Se distribuídas as informações entre empregados e empregadores (excluindo-se os ocupados por conta própria), tem-se uma ideia acerca da remuneração média de cada um dos dois grupos. Verificando essa informação para uma média das décadas de 1980, 1990, 2000 e período de 2010-2015, observa-se que os proventos do empregador excederam quase quatro vezes o percebido pelo empregado nos anos 80, e foi três vezes o valor da remuneração média deste no interregno 20102015, denotando, por conseguinte, uma ligeira redução dessa desigualdade (Tabela 5).

Tabela 5

Desigualdade das remunerações* médias dos empregados e empregadores (anos 80, 90, 2000, e período 2010-2015)

\begin{tabular}{l|c|c|c}
\hline & $\begin{array}{c}\text { Desigualdade de } \\
\text { remuneração } \frac{\pi}{w}\end{array}$ & $\begin{array}{c}\text { Remuneração média do } \\
\text { trabalho em } \mathrm{R}(w)\end{array}$ & $\begin{array}{c}\text { Remuneração média do } \\
\text { capital em } \mathrm{R} \$(\pi)\end{array}$ \\
\hline Anos 80 & 3,9 & $1.416,39$ & $5.575,72$ \\
\hline Anos 90 & 3,8 & $1.352,87$ & $5.173,62$ \\
\hline Anos 2000 & 3,1 & $1.445,00$ & $4.486,34$ \\
\hline $2010-2015$ & 3 & $1.809,31$ & $5.498,56$ \\
\hline
\end{tabular}

*Valores reais, a preços de setembro de 2015, atualizados pelo INPC.

Fonte: Elaboração dos autores a partir dos microdados da PNAD-IBGE.

O Gráfico 11 registra a evolução da participação dos salários na renda nacional no período de 1981 a $2015^{14}$. É possível notar um comportamento oscilante, com menor valor de $51 \%$ e maior de 57,6\%. A partir de 1995 a parcela dos salários tem uma tendência mais voltada à queda, voltando a crescer de forma mais proeminente a partir de 2004. Novamente, os dados indicam, portanto, uma melhora para a classe trabalhadora nos anos 2000.

(14) Para o período 1981 a 1989 utilizou-se a PNAD e de 1990 em diante, o SCN (Sistema de Contas Nacionais). 


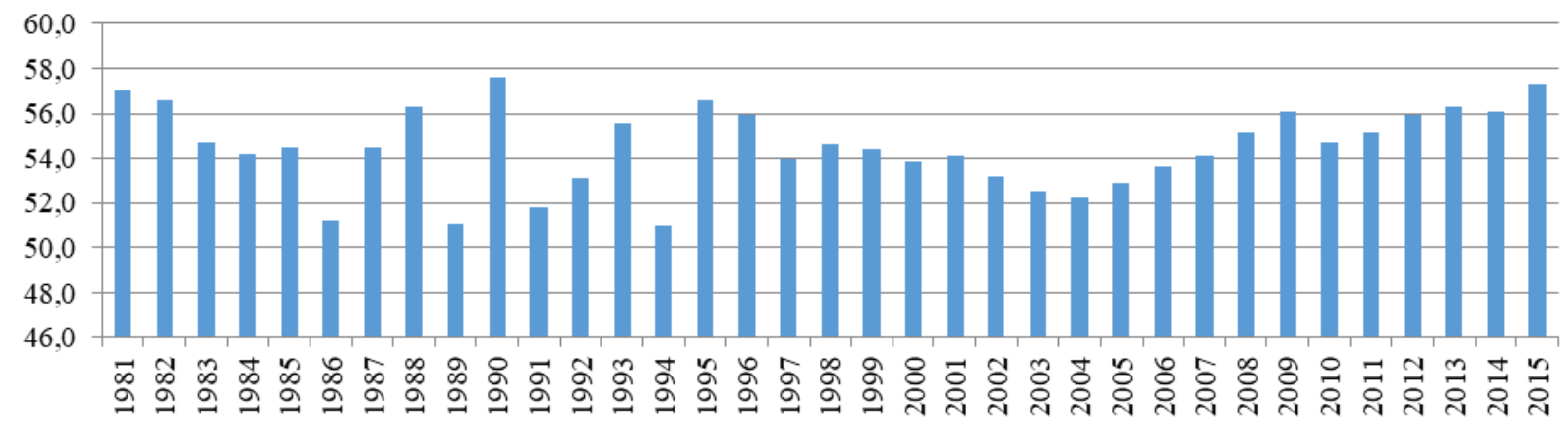

Fonte: Elaboração dos autores a partir dos microdados da PNAD-IBGE e do SCN.

Outro ponto importante a ser observado no mercado de trabalho diz respeito ao grau de formalização dos empregos gerados. No início dos anos 90, o grau de informalidade calculado pelo IBGE (definição do tipo $\mathrm{I}^{15}$ ) era de $56,4 \%$, ou seja, mais da metade dos entrevistados se enquadravam na condição informal (empregados sem carteira e os trabalhadores por conta própria). Esse percentual sofre uma queda de aproximadamente dez pontos percentuais durante o período analisado, chegando a 46,4\% no ano 2013, e 47,3\% em 2014 (Gráfico 12).

Gráfico 12

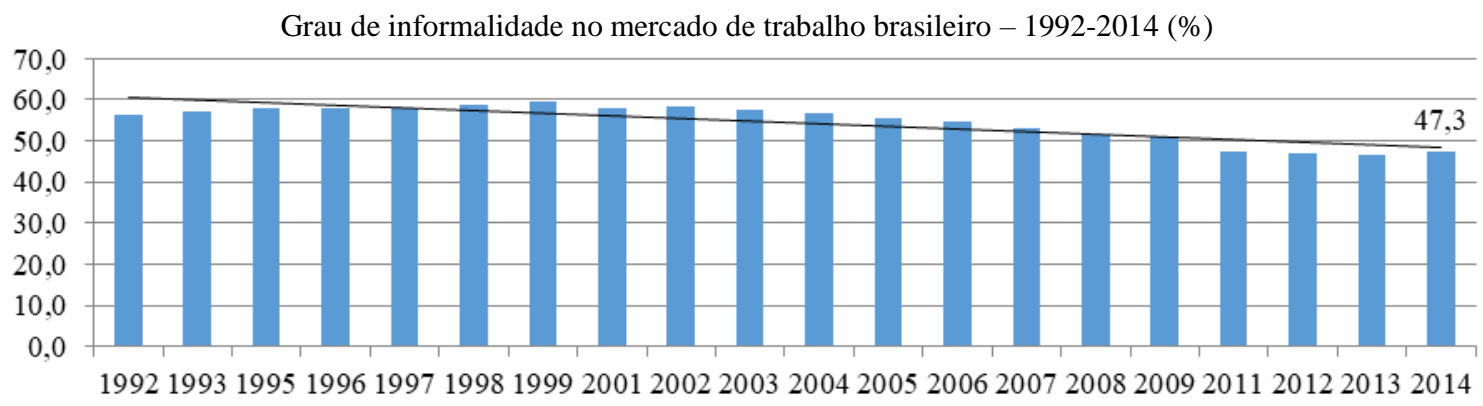

Fonte: Elaboração dos autores a partir de dados da PNAD-IBGE.

Apesar dos indicativos positivos para a classe trabalhadora que esses dados sugerem, é preciso qualificar esse quadro, ressaltando-se que mesmo a conjuntura favorável à dinamização da economia, elevando o emprego, o incremento da formalização que ocorre no período e a própria política de valorização do salário-mínimo não desconstroem as bases da desigual estrutura distributiva da renda no país. Por certo, isso pode ser atribuído ao fato de que, mesmo no referido período, se mantêm praticamente inalteradas determinadas estruturas de poder a partir de um sistema tributário regressivo, que confere tratamentos diferenciados às rendas do capital e trabalho, em favor do primeiro e, por outro lado, de uma estrutura fundiária concentrada.

(15) Uma das três diferentes definições do grau de informalidade oferecidas pelo IBGE é do tipo I que corresponde ao resultado da seguinte divisão: (empregados sem carteira + trabalhadores por conta própria) / (trabalhadores protegidos + empregados sem carteira + trabalhadores por conta própria). 
Mesmo no quadro relativamente positivo do mercado de trabalho, no qual os dados evidenciam que parte importante do aumento da absorção da população se deu de forma crescente pela via formal, cabe destacar que a informalidade ainda permaneceu bastante elevada no período, terminando em 47,3\% em 2014. Os dados do mercado formal, embora relativamente positivos, também contam com algumas ressalvas, conforme adiante.

Analisando apenas o mercado formal (Gráfico 13) nota-se que o crescimento dos vínculos empregatícios nos anos 2000 foi acompanhado de aumento da massa salarial e rendimento médio.

Gráfico 13

Evolução da massa salarial e da remuneração média real* no mercado de trabalho formal no Brasil - 2001-2016

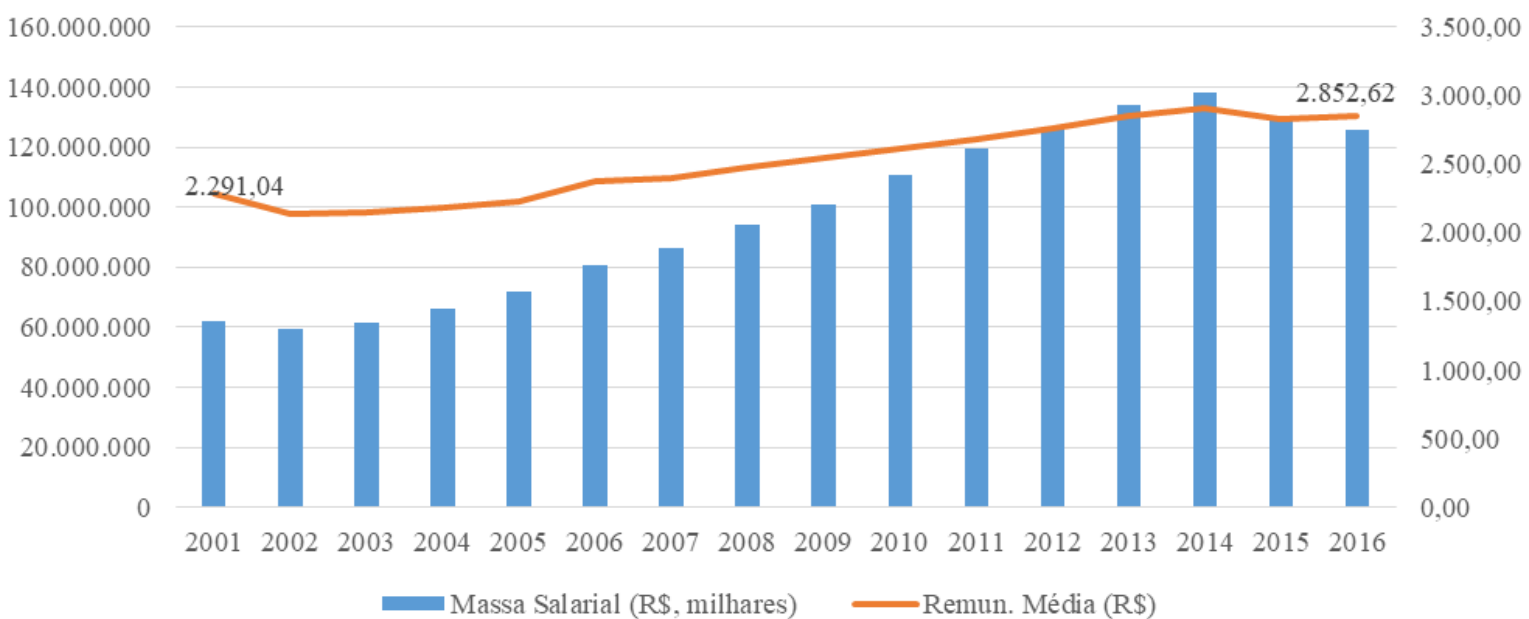

*Ambas em valores reais a preços de 2016, atualizados pelo INPC.

Fonte: Elaboração dos autores a partir de dados da RAIS.

A massa salarial conformada no mercado de trabalho formal no Brasil cresceu consideravelmente entre 2001 e 2016 (saltando de $R$ \$ 62 bilhões para $R \$ 125,8$ ), mesmo que este último ano reflita uma retração significativa. Entre 2001 e 2016, a massa salarial mais do que dobrou, com um incremento de $102 \%$, e se, ao invés do ano 2016, for tomado o ano 2014 como referência (ano em que ainda temos crescimento), o aumento chega a 122\%. Durante o interregno 2001-2016, percebe-se a ocorrência de uma retração em 2002, e depois, apenas em 2015 e 2016 como reflexo da crise política e econômica. A remuneração média do trabalho no mercado formal também evidenciou uma tendência majoritariamente ascendente no período em análise. Entre 2001 e 2016, ela aumenta em $24 \%$, e entre 2001 e 2014, aproximadamente $27 \%$. Esses dados reforçam os indícios acerca de um quadro relativamente positivo para a remuneração do trabalho.

Entretanto, apesar desses resultados, chama-se atenção para o fato de que boa parte dos trabalhadores brasileiros do mercado formal ganhou até dois salários-mínimos, e que o percentual de pessoas inseridas nesta faixa de rendimento aumentou consideravelmente ao longo dos últimos anos, chegando a 55\% dos formalmente empregados em 2016 (Gráfico 14). Isso sugere que parte expressiva dos empregos criados teve por característica uma remuneração mais baixa. 
Gráfico 14

Quantidade de trabalhadores formalmente empregados que ganhavam até dois salários-mínimos

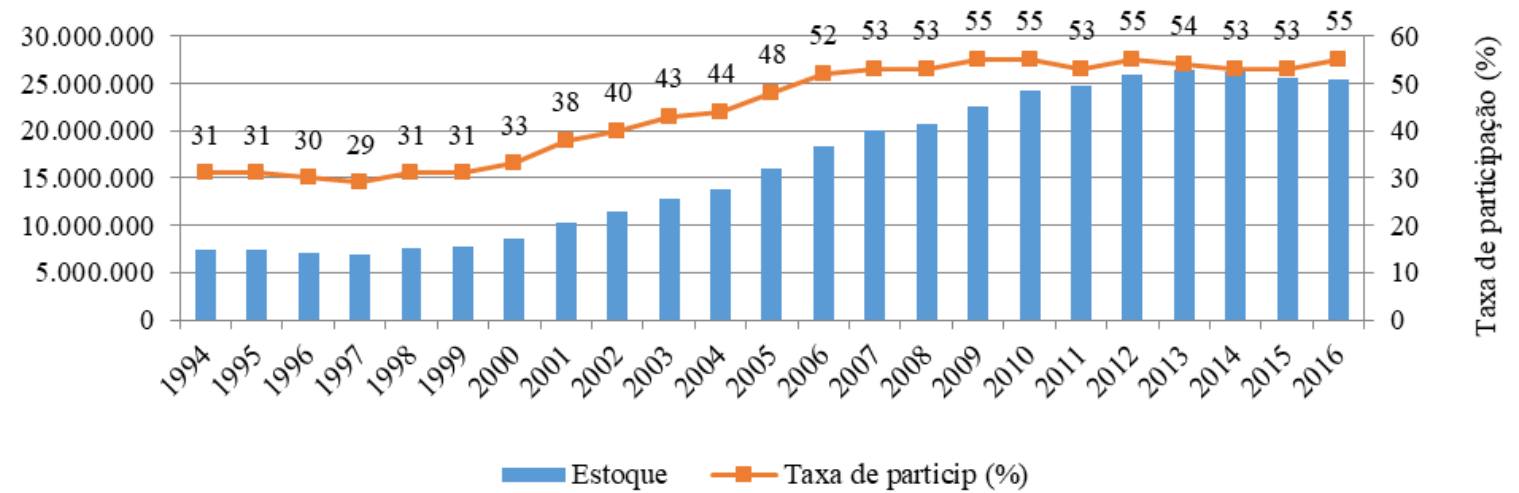

Fonte: Elaboração dos autores a partir de dados da RAIS.

Um último ponto tratado em relação aos dados do emprego, diz respeito à evolução da participação do setor de subsistência na economia brasileira. A obtenção deste dado foi feita a partir de uma apreensão mais ampla do setor, considerando que esta variável abrange, além dos trabalhadores não-remunerados e produtores para o autoconsumo, os subempregados na zona urbana. Com base em Bacha (1971), considerou-se a participação desse setor na economia fundamentalmente a partir do contexto de marginalização derivada dos rendimentos auferidos. A ocupação do indivíduo neste caso não lhe proporciona uma renda e, por conseguinte, consumo, mínimos e socialmente "referendados" pela sociedade no período vigente. Sob esta perspectiva, o limiar recorrido foi o salário-mínimo oficial.

Gráfico 15

Evolução da participação do setor de subsistência na economia brasileira - 1980 a 2015 (\%)

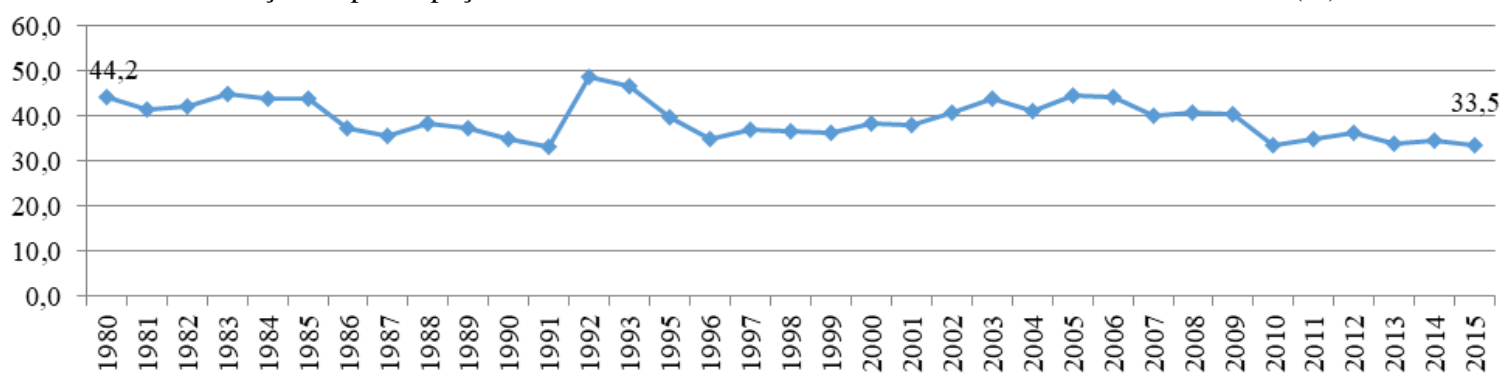

Fonte: Elaboração dos autores a partir de dados da PNAD e CENSO Demográfico.

O Gráfico 15 evidencia o percentual de pessoas ocupadas no setor de subsistência em relação ao total de ocupados, no interregno de 1980 a $2015^{16}$. Os dados apontam que o percentual de trabalhadores na subsistência era de $44,2 \%$ no início do período analisado e que, após paulatinas

(16) De 1980 a 2015 utilizou-se a PNAD, com exceção dos anos em que ela não foi realizada por ocasião do Censo Demográfico (e nestes casos, utilizou-se deste último), visando à captação dos ocupados por faixas de salários mínimos no rendimento da ocupação principal, a fim de obter a proporção dos que se colocavam abaixo do salário mínimo oficial para, assim, obter a participação do setor de subsistência. 
quedas, sobretudo de 2005 em diante, cai para 33,5\% em 2015. Apesar da tendência de redução observada, que contribui para diminuir as disparidades socioeconômicas do país, esse setor ainda tem uma participação notadamente relevante na economia brasileira, situando-se acima de $30 \%$.

De um modo geral, as informações evidenciadas para o mercado de trabalho denotam resultados relativamente positivos, os quais se colocam como importantes atenuantes da desigualdade no país. Essa dimensão da estrutura distributiva foi a que apresentou melhores resultados recentes, com potencial para desconcentração - ainda que confirmada a continuidade da heterogeneidade e a persistência de assimetrias relevantes neste mercado também.

Entretanto, mesmo se a análise distributiva ficasse circunscrita ao cenário específico do mercado de trabalho, permaneceria o questionamento acerca de até que ponto essas alterações positivas são de caráter permanente e, mais do que isso, se configuram condição suficiente para reversão da conformação díspar e concentrada da renda, a qual qualifica e reproduz o subdesenvolvimento brasileiro. A alteração da estrutura distributiva do Brasil implica modificações muito profundas e voltadas para elementos estruturais da constituição social e econômica do país. Ainda que algumas políticas mais conjunturais possam ter provocado algum reflexo sobre o quadro de desigualdades, elas se tornam ineficazes no que tange à alteração efetiva da dinâmica das correlações de forças, se não atacarem simultaneamente a espinha dorsal das principais estruturas de poder, que, por sua vez, está sedimentada em aspectos como o acesso à propriedade e a tributação sobre a renda e riqueza.

\section{Considerações finais}

O objetivo geral deste trabalho consistiu em evidenciar a natureza essencialmente distributiva do subdesenvolvimento em conformidade com a percepção de Celso Furtado, e, a partir dos elementos de base de sustentação de sua teoria, refletir acerca da atualidade e permanência desse diagnóstico para a economia brasileira, por meio de dados para o período mais recente, sobretudo no que diz respeito à elevada concentração e desigualdade de renda no país. A leitura de Furtado com respeito ao modelo brasileiro de crescimento e desenvolvimento atravessa os meandros da distribuição funcional da renda, por meio de uma análise que articula dependência externa e exploração interna.

O alto nível de exploração interna ao qual o subdesenvolvimento brasileiro faz jus se traduz na baixa socialização dos frutos do progresso técnico para o trabalho, concentrando-se estes, principalmente, para o capital. De tal modo, a obra furtadiana enfatiza a histórica compressão dos salários no país, tendo por base elementos estruturais, como a questão fundiária, dos quais se originam um setor de subsistência, que persiste ao longo do tempo.

A conformação do mercado de trabalho no Brasil é marcada pela dificuldade de incorporação da massa socialmente "amorfa" existente à época do período escravocrata, bem como dos próprios ex-escravos, findo este regime. Além disso, a imigração europeia contribuiu fortemente para acentuar a problemática da oferta elástica de mão de obra no país, e resultou no emprego de parte expressiva da população brasileira em ocupações mais degradantes, o que persistiu ao longo do processo de industrialização. Apesar de algumas transformações nesse período, o mercado de trabalho brasileiro continuou marcado por elevada heterogeneidade estrutural e o setor de subsistência, embora com 
características um tanto distintas, permaneceu relevante no que diz respeito à sua contribuição fundamental: a compressão das remunerações.

Os dados concernentes à estrutura fundiária do Brasil também permitem sua caracterização como altamente desigual e concentrada, sem modificações expressivas no período recente. Do mesmo modo, as informações relativas ao sistema tributário denotam uma estrutura altamente regressiva e um tratamento inusitadamente diferenciado para rendas do capital, o qual corrobora sobremaneira para a reprodução de assimetrias socioeconômicas no país.

O padrão de consumo, a despeito de alguma melhora no decorrer dos anos 2000, também continua marcado por elevada heterogeneidade, inclusive, em nível funcional. O mercado de trabalho, por sua vez, evidenciou uma trajetória relevante para redução da desigualdade e concentração da renda, sobretudo a partir da segunda metade da década de 2000. Para isso, contribuíram fortemente a diminuição do desemprego, o aumento da formalidade e a política de valorização dos salários. No entanto, mesmo diante dessas constatações, o grau de informalidade permaneceu bastante elevado e o setor de subsistência persiste com uma participação relevante na economia brasileira.

Todas essas constatações ajudam a qualificar o subdesenvolvimento brasileiro nos termos compreendidos por Celso Furtado, denotando sua característica elementar que reside na elevada heterogeneidade social, contribuindo também para apreensão da atualidade desse diagnóstico. A análise desses dados, à luz da teoria desse singular pensador, sugere que a superação do subdesenvolvimento requer a modificação de elementos histórico-institucionais que constituem expressão vívida das estruturas de poder no país, a exemplo do acesso à propriedade e do sistema de tributação de rendas e riqueza no país, cujas características de restrição e regressividade permanecem praticamente intocadas.

\section{Referências bibliográficas}

BACHA, E. L. El subempleo, el costo social de la mano de obra y la estrategia brasilena de crescimiento. El Trimestre Económico, out./dez. 1971.

BARBOSA, A. F. A formação do mercado de trabalho no Brasil: da escravidão ao assalariamento. Tese (Doutorado)-Universidade Estadual de Campinas. Instituto de Economia. Campinas, SP: [s.n.], 2003.

CARNEIRO, R. Padrões de consumo nos anos 1990 (Evidências preliminares). Economia $e$ Sociedade, Campinas, n. 17, p. 141-150, dez. 2001.

DATALUTA - Banco de Dados da Luta pela Terra, Universidade Estadual Paulista "Júlio de Mesquita Filho". Disponível em: http://www2.fct.unesp.br/nera/boletim.php.

DELGADO, G. C. Do "capital financeiro na agricultura” à economia do agronegócio: mudanças cíclicas em meio século (1965-2012). Porto Alegre: Ed. da UFRGS, 2012.

DELGADO, G. C. O setor de subsistência na economia brasileira: gênese histórica e formas de reprodução. In: JACCOUD, L. (Org.). Questão social e políticas sociais no Brasil contemporâneo. Brasília, DF: IPEA, 2004. p. 19-50. 
Alanna Santos de Oliveira, Carlos Alves do Nascimento

FAGNANI, E.; ROSSI, P. Desenvolvimento, desigualdade e reforma tributária no Brasil. In: A REFORMA tributária necessária: diagnóstico e premissas. Brasília: ANFIP: FENAFISCO; São Paulo: Plataforma Política Social, 2018.

FURTADO, C. Desenvolvimento e subdesenvolvimento. Rio de Janeiro: Fundo de Cultura, 1961.

FURTADO, C. Development and stagnation in Latin America: a structuralist approach. In: Studies in Comparative International Development, St. Louis, v. 1, 1965.

FURTADO, C. Subdesenvolvimento e estagnação na América Latina. Rio de Janeiro: Civilização Brasileira, 1966.

FURTADO, C. Análise do modelo brasileiro. São Paulo: Civilização Brasileira, 1972.

FURTADO, C. O mito do desenvolvimento econômico. Rio de Janeiro: Paz e Terra, 1974.

FURTADO, C. Prefácio a uma nova economia política. Rio de Janeiro: Paz e Terra, 1977.

FURTADO, C. Pequena introdução ao desenvolvimento: enfoque interdisciplinar. Rio de Janeiro: Cia. Editora Nacional, 1980.

FURTADO, C. Brasil: a construção interrompida. 2. ed. São Paulo: Paz e Terra, 1992.

FURTADO, C. O longo amanhecer: reflexões sobre a formação do Brasil. Rio de Janeiro: Paz e Terra, 1999.

FURTADO, C. [1967]. Teoria e política do desenvolvimento. São Paulo: Paz e Terra, 2000.

FURTADO, C. Em busca de um novo modelo: reflexões sobre a crise contemporânea. São Paulo: Paz e Terra, 2002.

FURTADO, C. [1959]. Formação econômica do Brasil. 34. ed. Rio de Janeiro: Companhia das Letras, 2007.

FURTADO, C. [1962]. Plano Trienal de Desenvolvimento Econômico e Social (1963-1965). In: D'AGUIAR, R. F. [Direção]. O plano trienal e o ministério do planejamento. Rio de Janeiro: Contraponto: Centro Internacional Celso Furtado, 2011. (Arquivos Celso Furtado, v. 4).

GOBETTI, S. W.; ORAIR, R. O. Progressividade tributária: a agenda negligenciada. Brasília, DF: Ipea, 2016. (Texto para Discussão, n. 219).

GOLLIN, D. Getting income shares right. Journal of Political Economy, Chicago, p. 458-474, Apr. 2002.

HADLER, J. P. T. C. Dependência e desenvolvimento: a transnacionalização do capital e a crise do desenvolvimento nacional em Celso Furtado. São Paulo: Alameda, 2012. 246p.

HOFFMANN, R. A subdeclaração dos rendimentos. São Paulo em Perspectiva, São Paulo, SEADE, n. 2, p. 50-54, 1988.

HOFFMANN, R. Estrutura fundiária e propriedade agrícola no Brasil. Brasília: Ministério do Desenvolvimento Agrário, 2010. 
HOFFMANN, R.; NEY, M. G. Desigualdade de renda na agricultura: o efeito da posse da terra. Economia, Niterói, RJ, Anpec, v. 4, n. 1, p. 113-152, jan./jun. 2003.

IBGE-PME - Pesquisa Mensal do Emprego. Disponível em: https://www.ibge.gov.br/estatisticasnovoportal/sociais/trabalho/9180-pesquisa-mensal-de-emprego.html?=\&t=o-que-e.

IBGE-PNAD - Pesquisa Nacional por Amostra de Domicílios. Disponível em: https://ww2.ibge.gov.br/home/estatistica/pesquisas/pesquisa_resultados.php?id_pesquisa=40.

IBGE-POF - Instituto Brasileiro de Geografia e Estatística. Pesquisa de Orçamentos Familiares. Disponível em: https://ww2.ibge.gov.br/home/estatistica/pesquisas/pesquisa_resultados.php?id_pesquisa=25.

IBGE- SCN - Sistema de Contas Nacionais. Disponível em: https://www.ibge.gov.br/estatisticasnovoportal/economicas/industria/9052-sistema-de-contas-nacionais-brasil.html?=\&t=o-que-e.

INTROÍNI, P. G. H.; DOS SANTOS, D. R.; SIQUEIRA, M. L.; CHIEZA, R. A.; TORRENTE, W.; LOEBENS, J. C.; FARIAS, F. M. G. B.; HICKMANN, C. Tributação sobre a renda da pessoa física: isonomia como princípio fundamental de justiça fiscal. In: A REFORMA tributária necessária: diagnóstico e premissas. Brasília: ANFIP: FENAFISCO; São Paulo: Plataforma Política Social, 2018. IPEADATA. Instituto de Pesquisa Econômica Aplicada. Disponível em: http://www.ipeadata.gov.br/Default.aspx.

KOWARICK, L. Capitalismo e marginalidade na América Latina. Rio de Janeiro: Paz e Terra, 1975.

KOWARICK, L. Trabalho e vadiagem: a origem do trabalho livre no Brasil. 2. ed. Rio de Janeiro: Paz e Terra, 1994.

LEÃO, I. Z. C. C.; OGAMA, D. F. O.; BILICKI, S. Cepal, Furtado, Kowarick e o debate sobre o mercado de trabalho. Economia e Sociedade, Campinas, v. 26, n. 3 (61), p. 539-559, dez. 2017.

MEDEIROS, M.; SOUZA, P. H. G. F.; CASTRO, F. A. A estabilidade da desigualdade de renda no Brasil, 2006 a 2012: estimativa com dados do imposto de renda e pesquisas domiciliares. Ciência e Saúde Coletiva, v. 4, n. 20, p. 971-986, 2015.

MORGAN, M. Income inequality, growth and elite taxation in Brazil: new evidence combining survey and fiscal data, 2001-2015. International Policy Centre for Inclusive Growth, 2018. (Working Papers, n. 165).

OECD - Organization for Economic Cooperation and Development. Disponível em: http://www.oecd.org.

OLIVEIRA, A. S.; NASCIMENTO, C. A. Uma análise do (sub)desenvolvimento brasileiro: um modelo de crescimento com distribuição de renda de regime "profit-led". In: ENCONTRO INTERNACIONAL DA ASSOCIAÇÃO KEYNESIANA BRASILEIRA, 12, Campinas, 2019.

RAMOS, P. Uma história sem fim: a persistência da reforma agrária no Brasil contemporâneo. In: BUAINAIN, A. M.; ALVES, E.; SILVEIRA, J. M.; NAVARRO, Z. [Ed. Técnicos]. O mundo rural no Brasil do século 21: a formação de um novo padrão agrário e agrícola. Brasília, DF: Embrapa, 2014. 1182p. 
Alanna Santos de Oliveira, Carlos Alves do Nascimento

RAIS-TEM - Relação Anual de Informações Sociais. Disponível em: http://portalfat.mte.gov.br/relacao-anual-de-informacoes-sociais-rais.

SOUZA, J. A elite do atraso: da escravidão à Lava Jato. Rio de Janeiro: Leya, 2017.

WASQUES, R. N. Estado e planejamento na obra de Celso Furtado. 2018. Tese (Doutorado em Economia)-Universidade Federal de Uberlândia, 2018.

WID - World Inequality Database. Disponível em: https://wid.world.

WDI - $\quad$ World Development Indicators. Disponível em: https://datacatalog.worldbank.org/dataset/world-development-indicators. 